\title{
„Bramy uniwersytetu otwarte dla klas pracujących!" Powojenna przebudowa imaginarium społecznego i projekt uniwersytetu socjalistycznego*
}

STRESZCZENIE. Każdy zryw modernizacyjny musi zakładać mobilizację do jego realizacji. Tak też było podczas odbudowy kraju po 1945 r. i budowaniu nowego socjalistycznego uniwersytetu. Przyjmując tezę o rewolucji społecznej, mającej miejsce w Polsce po 1939 r., zakładałam, że zmiana ta miała przynieść konsekwencje w przebudowie imaginarium społecznego oraz wykreowania pragnień edukacyjnych wśród klas pracujących. Horyzont pojęciowy uległ nieodwracalnej zmianie. Wspólne rozumienie spraw, zestaw horyzontów oczekiwań, typów idealnych i wiedza o naszej relacji do świata i innych grup uległy daleko idącym przekształceniom, tak w wyniku wojny, jak i powojennej odbudowy. Jaką rolę w nowej konstelacji pojęć odgrywały uniwersytety? Jakie obowiązki i przywileje przypisywano w prasie codziennej profesorom, studentom, ale także klasom pracującym i ogółowi społeczeństwa? Artykuł przedstawia analizę powojennej prasy codziennej nie jako narzędzie propagandy, ale język rekonstrukcji znaczeń. Rozbudzano pragnienia edukacyjne i poszerzano horyzont oczekiwań tych, dla których wcześniej edukacja, szczególnie na wyższym poziomie, była niewyobrażalna.

SŁOWA KLUCZOWE: uniwersytet socjalistyczny, prasa, nowe kadry, imaginarium społeczne, powojnie

\section{Wprowadzenie}

Pod koniec roku akademickiego 1947/48 studenci w jednej z łódzkich gazet mogli przeczytać ${ }^{1}$ :

* Projekt badania został wsparty przez Narodowe Centrum Nauki w ramach programu Preludium 2 (UMO-2011/o3/N/HS6/01948). Tematyka artykułu została rozwinięta w książce Punkty za pochodzenie. Powojenna modernizacja $i$ uniwersytet $w$ robotniczym mieście, Nomos, Warszawa 2016.

${ }^{1}$ Artykuł dotyczy powołanego właśnie ZMP. 
Wychowujemy człowieka wolnego, świadomego, że rozwija wszystkie swe twórcze siły indywidualne [...]. Wychowujemy człowieka współbojownika w szeregach wszystkich pracujących i walczących o lepsze jutro [...]. Wychowujemy człowieka, gotowego do wszelkich poświęceń i konsekwentnego w walce o ideały pełnego wyzwolenia, wspólnie odrodzonego naszemu narodowi i całej postępowej ludzkości (Nowa inteligencja ludowa $\mathrm{KP}$ 06/48)2.

To o nich był ten fragment. Prasa każdego dnia donosiła o nowych osiągnięciach nauki, wzywała do odbudowy kraju, zachęcała, by uczyć się i pracować. A uczyć się mieli wszyscy, dla każdego miały „stać otworem” także uniwersytety, szczególnie zaś dla tych, którym wcześniej trudno było przekroczyć jego progi. Modernizacyjny zryw, zmiana społeczna i przekształcenia instytucji to także procesy dyskursywne, realizujące się na poziomie przekształceń języka. Codzienna prasa, nawet jeśli poddana cenzurze i rażąca agitacyjnym językiem, współtworzyła powojenną rzeczywistość społeczną i proponowała konkretną wizję świata, w tym pragnienia edukacyjne i horyzont możliwości, dla powojennego pokolenia.

Artykuł śledzi rozwój nowej konstelacji znaczeń wokół koncepcji uniwersytetu socjalistycznego - jak zakładano, nowoczesnej uczelni o egalitarnej strukturze i dostępnej dla wszystkich klas społecznych, ze szczególnym uwzględnieniem klas pracujących. Analizuję dyskurs prasy codziennej wydawanej w Łodzi w latach 1945-1956. Baza danych powstała w wyniku badania kilku tytułów prasowych i selekcji artykułów dotyczących Uniwersytetu Łódzkiego. Materiał został zakodowany i poddany analizie jakościowej, aby zbadać, jak tworzyło się powojenne imaginarium społeczne oraz takie pojęcia, jak uniwersytet, student czy profesor.

Nowy język opisu nie był tylko narzędziem uwiedzenia mas przez totalitarną propagandę, miał wpływ na zyskiwanie podmiotowości politycznej przez kolejne grupy społeczeństwa. Przeciwstawiam się argumentowi o manipulacji mas - jeśli prasa miała mieć tyle perswazji i mocy sprawczej, aby „uwodzić”, czemu nie miała nieść emancypującego potencjału? Proponuję spojrzenie na kontrolowaną prasę socjalistyczną, które umożliwia wykroczenie poza ograniczenia analiz języka totalitarnego. Wbrew przyjętemu poglądowi o powojennej nowomowie, używana retoryka ma korzenie w XIX-wiecznej tradycji ruchu socjalistycznego oraz mobilizacji w pierwszych nowoczesnych rewolucyjnych zrywach, takich jak rewolucja $1905 \mathrm{r}$. Nawet jeśli była to jedynie dyskursowa emancypacja, oparta na hegemonicznej retoryce i nieprzekładająca się bezpośrednio na wymierne wskaźniki mobilności społecznej, to stanowiła ważny element powojennego projektu modernizacyjnego i jeden z nielicznych momentów w polskiej historii, kiedy to klasy pracujące znalazły się w centrum imaginarium społecznego, stając się podmiotem zmiany. Dodatkowo masowy wzrost czytelnictwa - dzięki zwiększeniu nakładów, nowym tytułom, pre-

${ }^{2}$ Cytując fragmenty z zebranej bazy artykułów, stosuję pisownię oryginalną oraz uproszczony zapis bibliograficzny (tytuł artykułu, skrót tytułu gazety, orientacyjny czas publikacji). 
numeratom zakładowym, kreowaniu nowych grup adresatów - czyni powojenną prasę codzienną istotnym środkiem kształtowania społeczeństwa.

Na kolejnych stronach czytelnik znajdzie wyjaśnienie używanego przez mnie terminu „imaginarium społeczne”, wprowadzenie do badania oraz analizę wybranych pojęć wraz z omówieniem ich konsekwencji dla społeczeństwa i budowy socjalistycznego uniwersytetu.

\section{Imaginarium społeczne}

Zmiana powojennego języka prasy codziennej to obszar kształtowania i konstytuowania się rzeczywistości społecznej, pojęć i obrazu świata. Każdorazowe użycie pojęcia jest wpisane w jego historyczne znaczenia. Prasa codzienna przedstawiała, a więc konstruowała świat - kształtowała imaginarium społeczne ${ }^{3}$. Nie chodzi jednak o proste samorozumienie ani zestaw wyznawanych idei. Jak wyjaśnia Charles Taylor, imaginarium jest tym, co umożliwia praktyki społeczne, nadając im sens. To także sposób istnienia rzeczy w pojęciu ludzi, który pozwala na realizację społeczeństwa przez wspólne rozumienie świata (Taylor 2012). To zestaw horyzontów oczekiwań, typów idealnych i wiedza o naszej relacji do świata i innych grup. Imaginarium to mapa społecznej przestrzeni. Określa ono także to, co w ogóle jest do pomyślenia w danym czasie historycznym - definiuje repertuar zbiorowych działań, będących do dyspozycji danej grupy czy klasy. Nowe rozumienie „zaczyna określać kontury [...] świata i z czasem może się stać oczywistym i prawdziwym kształtem rzeczy, o którym nie warto nawet wspominać" (Taylor 2010: 46). W rezultacie wykształca się nowa forma imaginarium społecznego.

Termin „imaginarium” spopularyzował ostatnio wśród polskich czytelników Andrzej Leder, modyfikując nieznacznie pojęcie Taylora i definiując imaginarium w psychoanalitycznym duchu jako „trwałe wyobrażenia funkcjonujące w świadomości i nieświadomości społecznej” (Leder 2014), figury zbiorowo przeżywanego dramatu. Zarówno Taylorowi, jak i Lederowi imaginarium służy do pokazania szerokich społecznych zmian w rozumieniu świata i tego, co jest w nim możliwe. Źródłem tych zmian są przede wszystkim wydarzenia i procesy historyczne, rozwój ludzkiej myśli i obieg idei.

Z kolei Benedict Anderson, będący inspiracją dla Taylora, pisząc o wspólnotach wyobrażonych, podkreślał rolę rozwoju technologii druku i gazet (Anderson i O’Gorman 1997). Nośnikiem imaginarium społecznego jest nie tyle intelektualna teoria zmieniająca oblicze świata, ile obrazy, opowieści czy legendy. Innymi słowy,

${ }^{3}$ Charles Taylor proponuje rozumieć imaginarium społeczne jako sposób, w jaki ludzie wyobrażają sobie swoją społeczną egzystencję, ich oczekiwania i normatywne założenia leżące u ich podstaw. Pojęcie to pojawiło się u Taylora stosunkowo późno (Taylor 2004), potem w niewielkim stopniu je rozbudowując, korzystał zeń w A Secular Age (Taylor 2007; 2010) 
kultura popularna (Garbowski 2012). Z tej perspektywy znaczenie narracji obecnych w prasie codziennej jest kluczowe dla kształtowania się społecznego imaginarium, zwłaszcza w „momentach węzłowych”, jakimi była Rewolucja Francuska czy druga wojna światowa. Opowieści czy narracje obecne w prasie powojennej tworzą na nowo ramy pojęciowe i konstelację sensów. Nawet jeśli zawarta w nich opowieść ma często imaginacyjny charakter, nie odbiera im to mocy, a raczej przydaje (Nowak 2008).

To właśnie prasa codzienna pozostaje najbardziej dynamiczną płaszczyzną użycia języka i tworzenia nowych sensów, to na papierowych stronach materializuje się i przekształca imaginarium społeczne. Gazety nie tyle tworzą informacje, ale przede wszystkim czytelników - przedefiniowują i utwierdzają podmioty grupowe (Grabham, Cooper, Krishnadas i Herman 2008); a nawet szerzej, jak wskazuje Allan Bell - także instytucje (Bell 1991). Konstelacje sensów definiowane i przetwarzane w prasie socjalistycznej miały więc istotny wpływ na imaginarium społeczne, odwzorowują je w pewien sposób, ale przede wszystkim tworzą. To w prasie codziennej najłatwiej uchwycić tworzące się lokalne reartykulacje programów nowoczesności, wzmożone powojennym modernizacyjnym zrywem i późniejszą hegemonizacją dyskursów prasowych przez oficjalny rządowy język (Howarth, Norval i Stavrakakis 2000). W pierwszym okresie to wspomniane wzmocnienie związane jest z „momentem węzłowym” - czasem odbudowy i ustanawiania na nowo porządku społecznego po drugiej wojnie światowej; w drugim po 1947 r. - z próbą stworzenia i narzucenia spójnego programu nowoczesności przez Polską Partię Robotniczą (później PZPR).

Jednak prasa socjalistyczna ujmowana jest najczęściej jako narzędzie propagandy, nowomowa czy język totalitarny. $Z$ jednej strony są to podejścia zamykające temat z powrotem w zimnowojennej sowietologii, z drugiej - pozostaje nie do zlekceważenia oraz niejednokrotnie trafnie i inspirująco określa specyfikę języka socjalistycznej prasy, zwłaszcza w okresie stalinizmu.

\section{Konfiguracja uczestników i procesów}

Przeprowadzone badanie materiałów prasowych obejmowało okres od 1945 do 1956 r., a w jego skład wchodziły wybrane tytuły trzech dzienników wydawanych w Łodzi, jak również tygodniki opinii oraz periodyki związane z polem akademickim. Szukałam artykułów dotyczących przede wszystkim Uniwersytetu Łódzkiego i nauki w Łodzi, ale także publikacje poświęcone życiu akademii w szerszym kontekście. Główny materiał badawczy stanowią trzy dzienniki wydawane w Łodzi: lokalny „Dziennik Łódzki” (DŁ), w latach 1953-1956 wydawany jako „Łódzki Express Ilustrowany” (ŁEI), ogólnopolski „Głos Robotniczy” (GR) - oba ukazujące się przez cały okres objęty badaniem; oraz „Kurier Popularny” (KP), wydawany do 1948 r. 
Najpopularniejszy dziennik po 1948 r. - „Trybuna Ludu” - w marginalnym stopniu poruszał kwestie Łodzi i jej uczelni, przez co został tu pominięty.

Socjalistyczna prasa zakładała zmianę adresatów prasy z oczytanej, miejskiej inteligencji na robotników, gdyż jej celem miała być legitymizacja i mobilizacja, a nie polityczne debaty czy recenzowanie poczynań władz. Jednocześnie model przedwojennego obiegu prasowego, strukturyzujący oczekiwania polskich czytelników, jak i przechowany etos dziennikarski pozwoliły zachować wiele z narodowej specyfiki prasy (Curry 1990). O ile w Związku Radzieckim prasa służyła jako narzędzie nauki czytania wśród niepiśmiennych w większości mas, kształtowała model czytelnictwa, definicje, czym jest i czemu służy obieg prasowy na najogólniejszym poziomie, o tyle w Polsce czytelnik, nawet o robotniczym pochodzeniu był już bardziej wyrobiony. Istniały więc ramy instytucjonalne, silne środowisko dziennikarzy i wydawców, a także oczekiwania czytelników - nie można mówić więc o prostej implementacji radzieckich rozwiązań. Tak czy inaczej, prasa pozostawała narzędziem bardzo wpływowym.

Jednym z najważniejszych wymiarów tworzenia imaginarium społecznego było nadawanie nowych sensów już istniejącym obiektom. Pojawiały się nowe określenia na uniwersytet, profesorów, studentów. Rodziły się także zupełnie nowe słowa, niosące nowe sensy, jak: nowe kadry, demokratyzacja, plan gospodarczy czy walka o pokój. W ten sposób powoływano do życia obiekty-podmioty, jak: studenci/ młodzież studiująca/słuchacze wyższych uczelni; kadra akademicka/profesorowie/ akademicy/wykładowcy wyższych uczelni czy wreszcie uniwersytet/szkoła wyższa/ uczelnia oraz nauka/wiedza/badania. Wymienione zbiory określeń oczywiście różnią się między sobą zakresem znaczeń i użyciem, jednak w tak niewielkim stopniu, że zostały potraktowane jako wspólne grupy synonimicznych określeń odnoszących do względnie stałych pojęć - obiektów niosących nowe sensy.

Nie jest bez znaczenia, że uniwersytet coraz częściej nazywany był szkołą wyższą, studenci - słuchaczami wyższych uczelni, studiowanie - zdobywaniem zawodu czy potrzebnej wiedzy, a nauka - badaniami dla gospodarki. Wzajemne relacje tych pojęć, częstotliwość ich występowania w czasie to oddzielny temat, mogący odsłonić zaskakujące związki uniwersytetu socjalistycznego z uniwersytetem przedsiębiorczym. Warto jednak przywołać analizy niemieckiej badaczki dyskursu Gerlinde Mautner, która zajmowała się narodzinami koncepcji uniwersytetu przedsiębiorczego (Mautner 2010). Jej rekonstrukcja debaty na temat urynkowienia uczelni i zmiany przypisywanych funkcji może posłużyć za inspirację dla niniejszej analizy. Grupy określeń - dla uproszczenia sprowadzone do kodowanych za pomocą wielu określeń pojęć, takich jak „studenci” czy „uniwersytet” - traktuję jako obiekty niosące nowe sensy, próbując jakościowo i możliwie zwięźle zbadać ich konstruowanie. Staram się ukazać, jak za pomocą języka przedstawiano i kształtowano domyślną rolę studenta, zakres przypisanych mu czynności, sprawczość i wzorce osobowe. 
Rola i zadania studenta związane są z samym procesem studiowania, któremu poświęcono $\mathrm{w}$ prasie wiele miejsca. $\mathrm{Z}$ dyskursu prasowego wyłania się model idealnej ścieżki kariery socjalistycznego studenta, który na różnych etapach powinien wypełniać swoje obowiązki. Najważniejszym procesem zachodzącym na uczelniach jest ich demokratyzacja, czyli zapewnienie dostępu do edukacji wyższej wszystkim obywatelom, a w efekcie tworzenie nowych socjalistycznych kadr - budowniczych socjalizmu. Proces ten kreślił zasadnicze ramy dla funkcjonowania uczelni, nauki i samych profesorów. Ci ostatni, podzieleni na częśc „postępową” i „reakcyjną”, musieli dokonać wyboru światopoglądowego - przede wszystkim kształcić nowe kadry. Rolę uniwersytetu, co interesujące, jakby oddzielonego od własnych pracowników, określano szerzej: miał umożliwić rozwój kraju nie tylko poprzez dydaktykę, ale i badania rozwojowe oraz doradztwo. Nowy socjalistyczny uniwersytet miał być przede wszystkim związany ze społeczeństwem, stąd ważna była także popularyzacja jego działań wśród obywateli.

\section{Studenci i studiowanie}

Tadeusz Wilk ze wsi Rudków, z powiatu opoczyńskiego, jest również synem małorolnego chłopa. Dość często czytał w dziennikach, że mamy w Polsce mało lekarzy, a szczególnie odczuwa się brak chirurgów. Wiele też słyszał o ogromnych postępach i osiągnięciach radzieckich chirurgów i ich nowoczesnej technice operacyjnej. Sprawy te mocno go interesują i postanowil, że zapisze się na medycynę (Wyższe uczelnie stoja otworem, GR 04/49).

Od momentu wyzwolenia kilkanaście tysięcy studentów, w tym Tadeusz Wilk, wyróżniały na ulicach miasta akademickie czapki. Podobnie jak na ogólniejszym poziomie, także przy definiowaniu w dyskursie, kim jest student i co oznacza studiowanie, pojawiło się pewne napięcie charakterystyczne dla starcia Łodzi akademickiej z robotniczą.

Jak przedstawiano w prasie, stanem wyjściowym, który należało zmienić, była niewłaściwa struktura społeczna studiujących i zagrożenie reprodukcją przedwojennych elit:

Zachodzi zjawisko charakterystycznej kontynuacji zawodów, powodującej olbrzymi napływ młodzieży na prawo, wydziały humanistyczny czy matematyczno-przyrodniczy. Zawód przechodzi z ojca na syna. Urzędnicy posyłają swoje dzieci na prawo, by w przyszłości powiększyły kadry administracyjne, nauczyciele chcą wychować swoich synów na bogów. Bardzo nikły jest jeszcze odsetek młodzieży chłopskiej i robotniczej 23 procent, co ma głębsze podłoże ogólne i specyficzne. Sześć bez mała lat okupacji uniemożliwiało synom chłopów i robotników kształcenie się. Młodzież inteligencka mogła dorywczo lub stale uzupełniać swoje braki na tajnych kursach, natomiast dzieci robotników i chłopów albo walczyły, albo musiały pod grozą utraty życia ponad siły 
pracować dla okupanta. Poza tym setki i tysiące ich zginęlo wywiezionych na roboty do

Niemiec (Uniwersytet u progu nowego roku..., GR 09/46).

Groziło to nasileniem się konfliktu między grupą chłopską i robotniczą, dążącą do przebudowy kraju i uznawaną za postępową siłę modernizacji (powojnie), a młodzieżą wywodzącą się ze sfer wyższych, która miała usiłować tę przebudowę powstrzymać (przedwojnie).

Wśród krytycznych głosów znajdziemy ostrzeżenia przed oderwaniem studentów od spraw społeczeństwa, przestrogi, jakoby stanowili „ostoję reakcji”, „zgromadzenie bumelantów”, wykorzystujących przywileje zapewnione przez państwo ludowe wysiłkami całego społeczeństwa (zwłaszcza robotników). Kiedy studenci „sprawiali kłopoty”, np. manifestując po zabójstwie Marii Tyrankiewiczówny w $1945^{4}$ czy choćby nie przykładając się do nauki, a nawet lekkomyślnie wybierając kierunek studiów, odpowiedzialne były za to zawsze działania czy to „reakcji”, czy wspomnianej „młodzieży przedwojennej”.

Prasa kilkakrotnie przedstawiała kolektywny głos robotników, mający upominać studentów i przypominać im, ile zawdzięczają ojczyźnie i innym członkom społeczeństwa, dzięki których trudowi mogą studiować i rozwijać się:

Ulokowanie wielkiej rzeszy młodzieży akademickiej w murach miasta - napotyka duże trudności. Ale młodzież jest niecierpliwa i nim zaczęła się na dobre uczyć zaczyna zarówno miastu jak i tym, którzy są jego prawdziwymi gospodarzami - zorganizowanym robotnikom, przysparzać coraz więcej zmartwień (Studenci muszq się liczyć..., DŁ 12/45).

Opisywano konflikt ze związkami zawodowymi o lokal restauracyjny, z którego chcieli korzystać studenci, związki zawodowe ostrzegały więc:

Należy przestrzec studentów - kończył ob. Burski - przed nierozważnymi krokami. Niedobrze by bowiem było, gdyby społeczeństwo rozczarowało się do nich [studentów - A.Z.] wcześniej, nim ich pokochało. Byłoby to ze szkodą zarówno dla nauki jak i dla samej młodzieży" (Studenci muszq się liczyć..., DŁ 12/45).

Robotnicy ostrzegali także przy obchodach 1-majowych w 1946 r., kiedy to „»grupka awanturników faszystowskich w czapkach studenckich « - ta nieznaczna grupa wywodząca się z »paniczyków« zakłóciła marsz" (Robotnicy ostrzegają, GR 05/46). W przypadku wszystkich tych interwencji na poziomie struktur wypowiedzi to klasa robotnicza zyskuje podmiotowość oraz możliwość oceniania i upominania studentów. Częściowo służy to uprawomocnieniu poczynań administracji partyjnej i państwowej, jakoby reprezentującej ową klasę. To klasa robotnicza i reszta

${ }^{4}$ Opinia publiczna podejrzewała o morderstwo na tle seksualnym żołnierzy radzieckich, lecz oficjalnie próbowano przypisać sprawstwo antyrządowemu podziemiu. Sprawa była szeroko dyskutowana i doprowadziła do manifestacji studentów (Spodenkiewicz 2008). 
społeczeństwa poświęcała się dla podtrzymania uprzywilejowania tej jednej grupy społecznej, zyskując jednocześnie prawo do kontroli i recenzowania poczynań studentów, jak i całego uniwersytetu. Mogła więc żądać nawet odebrania autonomii uniwersyteckiej, aby ukrócić wybryki »reakcyjnej części studentów«”.

Dominowały jednak głosy pozytywne i przychylne studentom, nawołujące do wspólnego wysiłku. Studenci jako grupa społeczna zostali obsadzeni po tej samej stronie barykady co robotnicy, a więc jako wykorzystywani i nieuprzywilejowani w czasach kapitalistycznych, a dziś otoczeni opieką państwa i całego społeczeństwa. Byli równoprawną częścią powojennego projektu. Przykładowo, kiedy Arturówek osiedle wśród lasów na północy Łodzi, słynące przed wojną jako siedlisko bogaczy - zajęły kwatery dla studentów, przedstawiano ten fakt jako przejaw sprawiedliwości społecznej. Kluczem do sukcesu projektu modernizacyjnego było przełamanie izolacji uczelni i „uspołecznienie” studentów. Nawet powojenny prezydent Łodzi, Kazimierz Mijal, znany ze swych sceptycznych poglądów na temat uniwersytetu, nawoływał o pomoc dla studentów i dołożenie wszelkich starań, by „poczuli się jak w domu”, co odbywało się właśnie pod ambiwalentnym hasłem „uspołecznienia studentów”. Częściej niż „bumelantami” studenci mieli być podstawą zmiany społecznej i nowymi socjalistycznymi kadrami, zapewniającymi postęp gospodarki i całego kraju.

Tak skonstruowany typ powojennego studenta musiał „stać na odpowiednim poziomie inteligencji, [...] wykazać odpowiednie zdolności do nauk teoretycznych, stać na wysokim poziomie moralnym i mieć jak najbardziej rozwinięty instynkt społeczny” (Ci, którzy dzieło ojców swoich rozwiążą i udoskonala, KP 06/46). Do zadań studenta socjalistycznego należały przede wszystkim: właściwy wybór studiów, wysiłek i poświęcenie studiowaniu, zaangażowanie w sprawy społeczne i aktywność, a po studiach służba krajowi i społeczeństwu.

\subsection{Wybór studiów}

Młody człowiek miał podjąc świadomy i odpowiedzialny wybór kierunku. Był to temat zajmujący dziesiątki artykułów. Skoro sytuacją wyjściową był brak kadr spowodowany stratami wojennymi oraz ogromny „wysiłek odbudowy” kraju, to każdy indywidualny wybór miał znaczenie. Stąd co roku przy okazji zapisów na uczelnie apelowano o świadome i odpowiedzialne decyzje, podejmowane nie z perspektywy własnych korzyści, ale całego społeczeństwa:

Liczny napływ na wyższe uczelnie, notowany bezpośrednio po wojnie, nie zmniejsza się. Miejsca dla wszystkich chętnych jest u nas, na szczęście, dość. Gorzej, że młodzież kieruje się przesłankami czysto materialnymi - masowo garnie się na wydziały lekarskie, prawne itp., nie doceniając innych, równie ważnych, jak humanistyka, przyroda $\mathrm{i}$ in. (Młodzież garnie się do nauki, DŁ 09/47). 
Po 1946 r. rozszerzono działania komisji rekrutacyjnych - czyli specjalnych komitetów prowadzonych przez organizacje studenckie (od 1948 r. przez ZMP), które miały na celu nie tylko informować o zasadach rekrutacji, ale także przeprowadzać z kandydatami życiowe rozmowy i doradzać w wyborze studiów:

Komisje, których zadaniem jest odpowiedni dobór młodzieży na poszczególne uczelnie i kierowanie każdego kandydata na studia, które byłyby najbardziej odpowiednie dla niego ze względu na uzdolnienia oraz możliwości intelektualne i zdrowotne, starają się przeciwdziałać tym zjawiskom [nietrafnemu wyborowi studiów - A.Z.] wyjaśniając młodzieży sens studiów w Polsce Ludowej. Przeprowadzają więc indywidualne rozmowy z osobami, które wybrały bez przemyślenia kierunek swoich studiów. [...] Są jednak także osoby, które myślą w dawny, charakterystyczny dla burżuazyjnego społeczeństwa sposób. Wbrew swoim uzdolnieniom chcą oni koniecznie pójść na medycynę czy politechnikę, bo ukończenie tych studiów zapewni im „dostatnie i spokojne życie”. Tak np. jeden z maturzystów posiadający uzdolnienie i zainteresowania muzyczne uparł się pójść na A M., inny znowuż mający wybitne uzdolnienia literackie - idzie na leśnictwo. Ludzie ci nie wiedzą, że w naszej ludowej ojczyźnie wszyscy mają zapewnioną pracę i ich obowiązkiem jest pracować w tej dziedzinie, w której mogą być najbardziej owocni (200o podań na wyższe uczelnie, DŁ 06/51).

Nie było miejsca na przedwojenne indywidualne fanaberie i tracenie czasu oraz pieniędzy z budżetu państwa. Ta promowana w prasie socjalistyczna merytokracja nie miała na celu skierowania jak największej liczby osób na kierunki bezpośrednio związane z przemysłem, ale zapewnienie możliwości rozwoju według zainteresowań. Miało to gwarantować oddanie pracy, a co za tym idzie - lepszą wydajność i większą korzyść dla ogółu. Gazety donosiły także, iż „niejednokrotnie komisja rekrutacyjna nakłania wprost do studiów kandydatów, którzy z różnych powodów chcą ich poniechać” (Dlaczego wybieracie ten kierunek, DŁ 06/52). Przestrzegano, że studenci mogą ulegać radom krewnych, namawiających na „popłatne” kierunki, a to są pobudki drugorzędne (Nad wtaściwym wyborem studiów, GR 12/53). Odradzano także studia $w$ innym mieście niż miejsce zamieszkania, aby nie narażać na koszty rodziny i państwa. Wraz ze wzmożoną retoryką walki o realizację planu sześcioletniego coraz więcej pisano o potrzebach państwa ludowego, co uzasadniało konieczność uwzględnienia przez przyszłych studentów „momentów społeczno-politycznych" (Ważna decyzja, GR 05/53).

Dodatkowo, podkreślając niedostateczną pracę nad kształtowaniem zainteresowań uczniów na poziomie szkół średnich, od lat 50. ogłaszano wiosenne akcje uświadamiające, czyli „dni otwarte” na uczelniach, punkty informacyjne i możliwość konsultacji z pracownikami akademickimi dla przyszłych studentów. Jednocześnie mówiono, że studia nie są dla każdego i nie jest to konieczny element ścieżki edukacyjnej, nawet dla posiadaczy matury. Przymus studiowania dla samego studiowania, niejako ze społecznego przymusu, był przedwojennym przeżytkiem: 
Znaczny odsetek młodzieży akademickiej stanowią jednostki, które nie zastanawiają się poważnie ani nad kierunkiem studiów wyższych, ani też nad ich potrzebą w ogóle i zapisują się na uniwersytet jedynie dlatego, że jest to formalna droga każdego człowieka posiadającego maturę. Podobny pogląd był wysoce charakterystyczny dla środowiska mieszczańskiego, gdzie dyplom uniwersytecki obok stopnia zamożności stanowił o pozycji towarzyskiej i był miernikiem oceny danej jednostki. Dziś pogląd ten należy już do przeszłości i dlatego też nie powinniśmy dopuścić do odrodzenia innego przeżytku przeszłości tzw. typu wiecznego studenta (Uwagi o studiach, DA 09/47).

\subsection{Wysiłek i poświęcenie studiowaniu}

Następnie, w czasie studiów, młodzież miała studiować sumiennie, a więc regularnie i punktualnie przychodzić na zajęcia, terminowo podchodzić do sesji, nie „opuszczać się" w nauce, systematycznie pracować nad materiałem, nie wybierać dróg na skróty. Zwłaszcza od lat 50. zwiększano nacisk na produktywność i wyniki studiowania, a od studenta wymagano dobrego planowania i zarządzania swoim czasem:

Poważną ilość zajęć oraz konieczność odpowiedniego przygotowania się do nich zmuszą studenta do jak najracjonalniejszej gospodarki czasem. Każdą minutę chce on odpowiednio wykorzystać bądź na wykładach i ćwiczeniach, bądź też na przygotowaniu do nich. Nakłada to na władze uniwersyteckie obowiązek odpowiedniego rozłożenia zajęć w ciągu dnia i ścisłego przestrzegania tego planu również przez personel naukowy (Socjalistyczna dyscyplina, DŁ 11/51).

Coraz większy nacisk kładziono na planowanie pracy, organizację, „aktywne współzawodnictwo" i pracę w grupach. Nowa dyscyplina studiów, wprowadzana od 1948 r., miała odróżnić socjalistyczny uniwersytet od przedwojennego liberalnego:

Zlikwidowana została dawniej tak popularna „giełda”, która polegała na wystawaniu pod gabinetem przeprowadzającego egzaminy profesora w celu zasięgnięcia informacji, ,jak pyta” i „o co najczęściej pyta”. Na podstawie tych uzupełnianych pośpiesznie przerzuceniem skryptu „wiadomości”, przygotował się zazwyczaj student liberalnego uniwersytetu do egzaminu. Otóż na tym odcinku zaszły bardzo poważne zmiany. Dziś - zamiast „giełdy” istnieją zorganizowane grupy studenckie odbywające zajęcia według ustalonego planu godzin. Studenci, którzy wspólnie słuchają wykładów, wspólnie odrabiają ćwiczenia, winni również wspólnie się uczyć (Dyscyplina studiów i zespołowa praca, GR 09/51).

Wiązało się to zresztą z nasilająca się od początku retoryką rewolucyjną, używającą słownictwa militarnego do opisu akademickich spraw. Nauka stała się takim samym obszarem walki o wykonanie planu sześcioletniego, jak hutnictwo czy przemysł włókienniczy - grupy studentów lub całe uczelnie miały podejmować 
współzawodnictwo, rzucając sobie wzajemnie wyzwania. Absolwenci mieli tworzyć „olbrzymią armię budowniczych socjalizmu” czy stać się „oficerami budownictwa socjalistycznego" (Nowy rok - nowe zadania, GR 10/53). Niczym w wojennych potyczkach, uczelnie przechodzily przez „decydujące dni”, „natarcia” etc. Tak zagrzewał do walki „Dziennik Łódzki”:

„Przodownicy idą na najtrudniejsze odcinki” - głosi apel ZG ZMP o zaciągu pionierskim. Ruchem masowego przodownictwa w nauce i pracy społecznej odpowiedzą studenci UŁ na ten apel. Stawiając przed sobą większe niż dotychczas zadania mobilizując siły dla ich wykonania - dotrzymywać będą kroku swym kolegom z kopalni i hut (Studenci Uniwersytetu Łódzkiego podejmują ruch masowego przodownictwa, DE 03/53).

W tym walecznym pochodzie kluczową rolę odgrywała świadomość polityczna i nastawienie do wykonywanych zadań. Miernikami sukcesu podawanymi przez prasę były przede wszystkim wyniki sesji, procent studentów podchodzących do egzaminów oraz ich zdawalność. Okres sesji był więc czasem wytężonej „walki” i sprawdzianu nie tylko umiejętności studentów, ale także sprawności działania całej instytucji. Tak w 1953 r. rektor Szczepański ogłaszał przełom w walce na UŁ:

Główną przyczyną naszych osiągnięć jest niewątpliwie systematyczna, rytmiczna praca w ciągu całego drugiego półrocza. Co miesiąc odbywały się kolokwia sprawdzające. Jeśli student nie zdał takiego kolokwium, otrzymywał natychmiast indywidualną pomoc asystenta. [...] Młodzież pracowała w grupach, kierowanych przez organizację ZMP-owską. Powtarzanie materiałów odbywało się w zespołach repetytorskich. Nad każdą grupą studencką czuwał i kontrolował jej pracę, a jednocześnie przeprowadzał stałe konsultacje - asystent - opiekun grupy. Wzmogła się też znacznie opieka nad studentami mieszkającymi w domach akademickich. We wszystkich domach asystenci pełnili codzienne dyżury, pomagali studentom w nauce. Wzmogła się dyscyplina pracy wszystkich ogniw Uniwersytetu. Zmniejszyła się liczba studentów nieobecnych na seminariach. Uniwersytet Łódzki potrafił przełamać trudności i dokonać olbrzymiego przełomu (Wielki przełom na Uniwersytecie Łódzkim, DŁ 07/53).

Najlepiej jednak, kiedy wysokie wyniki osiągano po prostu, a nie w rezultacie specjalnie obmyślonych działań (co ciekawe materiał dotyczy tej samej sesji zimowej, która stanowiła negatywny punkt odniesienia w przedstawionej wyżej wypowiedzi Szczepańskiego):

Wyniki uzyskane przez studentów w ostatniej sesji zimowej są tym cenniejsze, że w przygotowanie sesji włożono daleko mniej wysiłku administracyjno-organizacyjnego [...] dobre oceny są wynikiem jedynie niespotykanego dotychczas wzrostu poczucia obowiązkowości i dyscypliny studiów wśród studentów. Na dodatni przebieg sesji miał także poważny wpływ nowo wprowadzony system stypendiów premiowych (O wynikach zimowej sesji, GR 03/54). 
Plan szkoleniowy musi być wykonany, gdyż Polska Rzeczpospolita Ludowa czeka na naukowca, nauczyciela, administratora, prawnika, kierownika laboratorium itp. Uniwersytet nie może dopuścić do marnotrawstwa wkładanego wysiłku umysłowego i finansowego. Każdy złożony przez studenta egzamin - to krok naprzód. Ale dzisiaj walczymy już nie tylko o dobry wynik ilościowy, lecz i o jakościowy. Uniwersytet mobilizuje do sesji egzaminacyjnej swe siły nie tylko w celu uzyskania największej ilości zdających, ale i jak największej liczby studentów dobrze zdających egzaminy ( $O$ wynikach zimowej sesji, DŁ 02/53).

Co sesję raportowano wskaźniki odsiewu, czyli liczby osób, które nie zdały sesji, oraz odpadu osób, które do sesji nie przystąpiły. Już od 1950 r. prasa donosiła, iż sami studenci debatują, jak je zmniejszyć (Młodzież akademicka podnosi..., GR 04/50). Przyczyn odpadu i odsiewu upatrywano w słabym przygotowaniu studentów przez szkoły średnie, a czasem i w działaniach wspominanych złych sił. Wysiłki studentów mierzone były także obecnością na zajęciach i rozkładem pochodzenia społecznego.

\subsection{Zaangażowanie w sprawy społeczne i aktywność}

Jednocześnie student miał pozostawać świadomym obywatelem, prowadzić dodatkowe aktywności, a także nie poddawać się reakcyjnym siłom, a walczyć z nimi. Nacisk ten miał być tym wyraźniejszy w Łodzi:

Najmłodsze w Polsce miasto posiada najmłodszy w świecie uniwersytet, bez wiekowych tradycji, bez przeszłości, jak inne uczelnie polskie i fakt ten nakłada na młodzież wielką odpowiedzialność przed przyszłymi pokoleniami łódzkich Akademików. Studenci łódzkich wyższych uczelni winni stać się pionierami nowej myśli, bastionem wykuwania nowej inteligencji w odrodzonej, demokratycznej Polsce (Inauguracja roku, DŁ 10/45).

Studenci mieli więc aktywnie brać udział w życiu kulturalnym, pracach organizacji studenckich, akcjach żniwnych, spisach powszechnych (jako ankieterzy) oraz najlepiej nie pracować zarobkowo.

Praca zarobkowa studentów zajmowała znaczne miejsce w prasowych rozważaniach. Był to temat rodzący wiele napięć: młodzież powinna wywodzić się z klas pracujących i powinna poświęcać się tylko studiom. Choć system stypendiów, domów akademickich, darmowych lub tanich posiłków rozwijał się z każdym rokiem, to znaczna część studentów musiała pracować zarobkowo, aby w ogóle móc studiować. Była to w dużej mierze młodzież przyjezdna ze wsi oraz młodzież robotnicza, która nawet jeśli kształciła się w miejscu zamieszkania, to i tak musiała pozyskać dodatkowe przychody na utrzymanie lub pomoc rodzinie. W 1948 r. alarmowano, że większość studentów nie ma czasu wolnego, gdyż 90\% pracuje (Studenci maja dużo humoru, ale mało pieniędzy, DŁ 11/48). 
Apelowano więc o dostosowanie terminów zajęć i wykładów oraz godzin prac dziekanatów do osób pracujących, a do ich przełożonych w miejscach pracy o umożliwienie wychodzenia na zajęcia czy odciążenie w czasie sesji. Nic dziwnego, że zwłaszcza zakłady pracy z nałożonymi normami produkcyjnymi nie miały żadnego powodu, by pomagać pracownikom studiującym, którzy wcześniej czy później odejdą z zakładu do innego rodzaju pracy, zgodnej z nowo zdobytym wykształceniem. Sytuacja jednak przedstawiana była inaczej, jeśli to niewprawna młodzież zabierała się do pracy (w domyśle zamiast się uczyć). Przykładowo w 1946 r. szydzono z pomysłu zatrudniania studentów w charakterze kelnerów. Miało to zaszkodzić tak zawodowym kelnerom tracącym miejsca pracy, samym studentom nieznającym fachu, źle obsługiwanym klientom, jak i właścicielom restauracji, którzy zamiast obniżać koszty, obniżali jakość obsługi (Studentki podają kawę, KP 07/46). Z jednej strony studentowi pracującemu należała się opieka i troska, z drugiej - praca podczas studiów nie była pożądana:

Jan pracuje na kolei. Nieraz zarwie kawał nocy, a rano musi być już w pracy. Jan studiuje polonistykę. - Ot, - mówi - nie chcę stać w miejscu. Pragnę rozszerzyć swój horyzont myślowy. Chcę dużo wiedzieć i dużo umieć. Pięknie. Ale przypatrzmy się nauce Jana. Przychodzi do domu zmordowany około godziny trzeciej. W pośpiechu łyka obiad i biegnie do tramwaju. I tak już spóźni się na pierwszą godzinę wykładu. Zgoniony dopada wreszcie drzwi sali wykładowej, prześlizguje się cicho do środka i wsuwa się na jakieś wolne krzesło. Wykład jest w toku. Miarowy, nieco zbyt cichy głos profesora to jest właśnie wiedza, której Jan łaknie, jak chleba. Nastawia więc czujnie uszu i chłonie ten głos. Po paru jednak minutach słowa wydają się oddalać od niego, przed oczyma jakby ktoś rozciągnął zasłonę, głowa opada na piersi. Jan drzemie (Jan drzemie na wyktadzie, DŁ 09/48).

Mimo szczerych chęci Jan nie osiągnie swoich celów, czytelnik z dystansu widzi bezsens jego starań i groteskowość jego postaci. Podobnie wygląda sytuacja Piotra i Stefana, dla jednego praca w biurze, dla drugiego udzielanie korepetycji jest przeszkodą w studiowaniu:

Takich jak Jan, jak Piotr, jak Stefan jest w Łodzi przynajmniej kilkanaście tysięcy. Zadajemy sobie pytanie czy oni są winni, że drzemią na wykładach, że uczą się powierzchownie, że nie mają czasu na studia w bibliotece? Nie. Winne są ciężkie warunki materialne, w jakich muszą dziś studenci zdobywać naukę. A zagadnienie jest poważne, gdyż narastają rzesze niedouczonych lekarzy, inżynierów, prawników. Niedouczonych powtarzam, nie z ich winy i nie z winy wyższej uczelni, wydającej im dyplomy (Jan drzemie na wykładzie, DŁ 09/48).

W polemice z powyższym stanowiskiem pisano zaś, co można wpisać w szerszą dyskusję o obniżaniu poziomu studiów, iż praca nie stoi na przeszkodzie nauce, wystarczy się bardziej starać: 
Liczni studenci pracują zarobkowo i są równocześnie aktywnymi działaczami społecznymi i politycznymi. Dodamy, że ludzie ci z reguły czynią największe postępy w nauce. [...] Czas najwyższy uświadomić sobie, że w okresie odbudowy, gdy szerzy się idea przodownictwa pracy, a robotnicy swym trudem fizycznym i umysłowym biją rekordy produkcji, akademika także stać na wytężoną i wszechstronną pracę (Dyskusja o stypendiach, D€ 10/48).

Słabe wyniki to nie efekt obiektywnej sytuacji materialnej i niewystarczającego wsparcia studiujących, ale indywidualnych cech. Artykuł miał przede wszystkim pełnić funkcję mobilizującą do wysiłku odbudowy i wyrzeczeń w imię lepszej przyszłości.

Wraz z reformą pracujący, by studiować i utrzymać rodzinę, stawał się bohaterem prasy, „stachanowcem” akademii łączącym te trudne do pogodzenia sfery aktywności, oczywiście z sukcesem. Tak pisano o studentach kursu przygotowawczego:

\begin{abstract}
Abiturienci to przeważnie robotnicy, którzy przez cały czas trzyletniej nauki w szkole pracowali przy swych codziennych warsztatach. Większość z nich ma na utrzymaniu rodziny. Pomimo obowiązków i pracy zarobkowej, robili bardzo dobre postępy w nauce. Co zamierza pan studiować? - pytam powracającego z egzaminu Tadeusza Białowiejskiego. Zapisuję się na prawo; mam co prawda na utrzymaniu rodzinę, ale pogodzę jakoś studia z pracą zarobkową - pada odpowiedź (Goniec - magazynier - referent - student UŁ, DŁ 07/49).
\end{abstract}

Mimo wszystko w większości artykułów raczej potępiano pracę studentów poza tak uzasadnianymi przypadkami jak powyższy. Jednocześnie studenci mogli pracować społecznie, oddając niejako społeczeństwu to, co od niego otrzymali już w czasie studiów. Praca społeczna miała być mniej uciążliwa, za to rozwijająca i mniej kolidująca ze studiami. Modelowy student, poza żywym zainteresowaniem sytuacją kraju, powinien aktywnie działać na uczelni, udzielać się w organizacjach studenckich (od 1948 r. obowiązkowo w ZMP), budować solidarne relacje towarzyskie i prowadzić rozmaite aktywności kulturalne (Kochanowicz 2000). Studenci byli zachęcani do różnego rodzaju przedsięwzięć: budowali linie tramwajowe, kopali doły pod ulice, stawiali domy akademickie dla swoich kolegów, o czym z dumą raportowano $\mathrm{w}$ prasie. $\mathrm{W}$ latach późniejszych zobowiązani byli wspomagać chłopów podczas żniw:

Już na początku turnusu brygada żniwna w gospodarstwie Dziedno wezwała do współzawodnictwa pozostałe gospodarstwa, w których pracowali nasi studenci [...] Brygada ta całkowicie wywiązała się z podjętego zobowiązania, a pozostałe gospodarstwa podjęły apel o zorganizowanie współzawodnictwa, które zakończyło się zwycięstwem brygady studenckiej z gosp. Mąkowarsko 11 ( $W$ polu też dali sobie radę, DŁ 08/53). 
Aktywność w czasie studiów była gwarancją spełnienia postulatu „uspołecznienia studentów" i zacieśniania więzów między społeczeństwem a studentami, dokonywanego pod opieką władz.

\subsection{Praca - służba krajowi i społeczeństwu}

Tak wykwalifikowana kadra, bez względu na to, czy ukończyła filologię, chemię czy medycynę, miała służyć modernizacji kraju: najpierw odbudowie po wojennych zniszczeniach, potem przy wzmagających się werblach rewolucyjnej retoryki - realizacji sześciolatki. Ponownie istotnym odniesieniem stawało się przedwojnie, przedstawiane jako czas produkcji bezrobotnych, kiedy uniwersytety nie były zainteresowane potrzebami społeczeństwa i gospodarki kraju. Inaczej wyglądała przyszłość absolwentów w rzeczywistości powojennej - jednym z najważniejszych postulatów władz, a sztandarowym hasłem PZPR stała się likwidacja bezrobocia, a termin „prawo do pracy” został wpisany w wizję nowoczesnego społeczeństwa:

[...] na absolwentów wszystkich wydziałów czekają fabryki i szkoły, huty i rolnictwo, czekają wszystkie gałęzie gospodarki narodowej. Zjawisko bezrobocia zginęło bezpowrotnie. Nie ma zawodów uprzywilejowanych, każdy obywatel Polski Ludowej ma prawo do pracy, każda praca jest zaszczytem (Ważna decyzja, GR 05/53).

Ważne było, aby wszyscy znaleźli pracę zgodną ze swoimi kwalifikacjami i by wysilek ten nie został zmarnowany.

Jednym z elementów reformy nauki i parametryzacji był postulat związania nauki z przemysłem poprzez praktyki studenckie. Miały one przygotować studentów do przyszłych wyzwań i zapoznać z realiami świata pracy:

Istotną cechą organizacji toku studiów wyższych w Polsce Ludowej jest harmonijne łączenie wysokiego poziomu teoretycznego z przygotowaniem do bezpośrednich zajęć praktycznych w życiu gospodarczym, społecznym i kulturalnym. Jedną z form realizacji tego postulatu organizacyjnego są praktyki wakacyjne (Otoczymy opieka mtodzież akademicka, DŁ 06/53).

Uczelnie miały podejmować współpracę z potencjalnymi miejscami pracy studentów, co dodatkowo wiązało się z fundowaniem specjalnych stypendiów przez zakłady pracy - ich pobieranie zobowiązywało do późniejszego podjęcia pracy na wyznaczonym przez zakład stanowisku. Co interesujące, także stypendia przyznawane przez Miejską Radę Narodową dla najwybitniejszych studentów przewidywały odpracowanie w którejś z miejskich komórek dokładnie takiego czasu, przez jaki pobierano stypendium 5 . Pracę dla studentów miało zapewnić przede wszystkim planowanie rekrutacji wprowadzone od 1949 r. Ściśle określona liczba przyjmowa-

${ }^{5}$ APŁ, mikrof. 120304, posiedzenie Miejskiej Rady Narodowej w Łodzi z 14 marca 1946 r. 
nych na studia, kontrolowana później w corocznych sprawozdaniach, pozwalała na wprowadzenie przydziałów pracy z ministerialnego rozdzielnika. W prasie budowano wokół tego tematu pozytywne skojarzenia:

Studentów zainteresuje niewątpliwie, że władze uniwersyteckie posiadają już odpowiedni rozdzielnik, wg którego absolwenci UŁ zostaną skierowani do prac w instytucjach podległych poszczególnym ministerstwom. Trzeba tu stwierdzić, że wachlarz zainteresowanych ministerstw jest bardzo szeroki, co dowodzi, że zapotrzebowanie na absolwentów jest olbrzymie. Pracy na nich czeka sporo. Jest to wreszcie dowodem ogromnych możliwości, jakie Państwo Ludowe daje absolwentom wyższych uczelni (Praca i mieszkanie zapewnione, DŁ 06/52).

Zadania studenta:

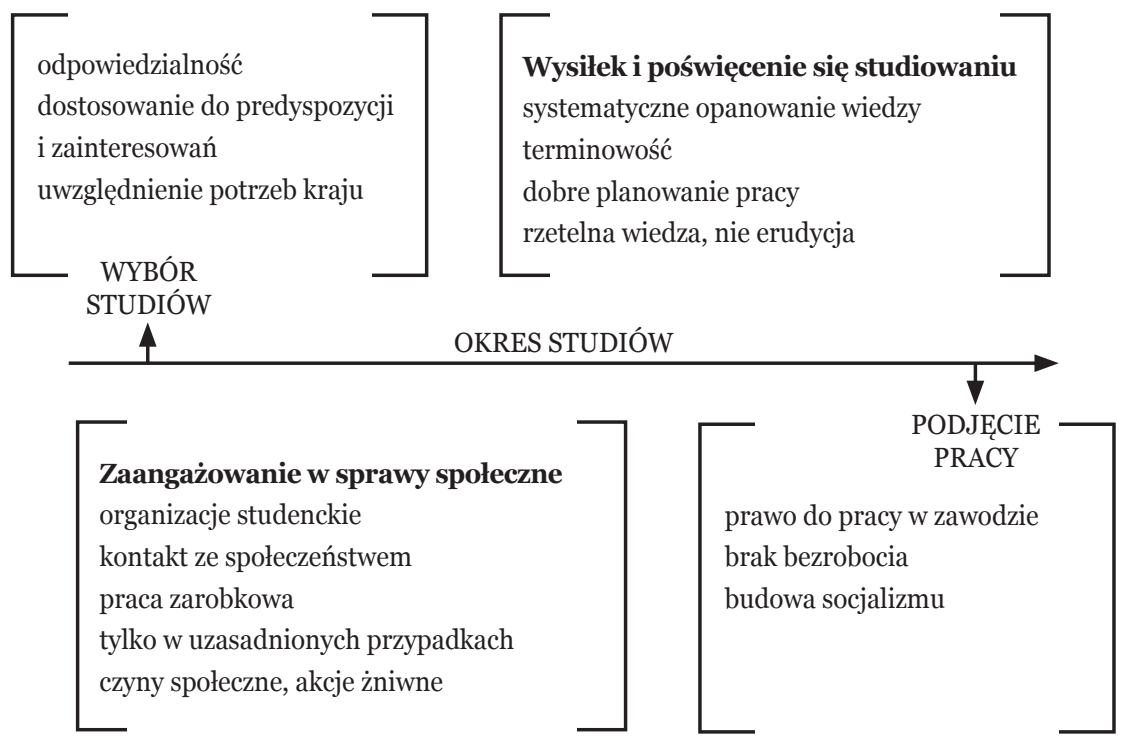

Rysunek 1. Zestawienie najważniejszych etapów

Źródło: opracowanie własne.

Prawo do pracy było zagwarantowane przez państwo ludowe. Ta gwarancja była istotnym komunikatem dla wielu ludzi, którzy po czasach wojennej zawieruchy pragnęli - czy to dla siebie, czy dla własnych dzieci - praktycznych umiejętności gwarantujących zatrudnienie bez względu na okoliczności. Jak wskazywano niejednokrotnie w wywiadach biograficznych i wspomnieniach z tamtego okresu, umiejętności praktyczne były wysoko cenione, wielu zapewniły przetrwanie w trudnych czasach. W dobrze zaplanowanej strukturze socjalistycznego uniwersytetu, jeśli otwierano jakiś kierunek i przyjmowano studentów, to miało to oznaczać, że dla 
takiego zawodu jest miejsce w społeczeństwie. Podsumowując, w prasie stworzono typ idealny powojennego studenta - miał być to wzorzec dla awansującej młodzieży z klas pracujących ${ }^{6}$ (rys. 1). Przykłady studentów, retoryka troski, wizja wyzwań, którym jednak można sprostać, miały uczynić wybór studiów realnym dla szerokich grup społecznych.

\section{Ku przyszłości - nowe kadry i demokratyzacja}

W Polsce, choć w mniejszym stopniu niż w Związku Radzieckim, obecny był kult wiedzy i nauki jako środka do modernizacji kraju. Zadaniem stojącym także przed uniwersytetem była produkcja nowych kadr. W pierwszej kolejności celem było nadrobienie strat wojennych. Był to argument stosowany do legitymizowania ważności szkolnictwa wyższego. Można powiedzieć, że nowe kadry służyły legitymizacji potrzeb całego pola akademickiego. Powojenna odbudowa wzmagała zapotrzebowanie na lekarzy, inżynierów, urzędników, nauczycieli: „praca czeka, a rąk ciągle za mało" (Jak najwięcej światlych ludzi..., GR 08/48) apelowano jeszcze trzy lata po wojnie.

Struktura pochodzenia społecznego nowych kadr miała odpowiadać strukturze całego społeczeństwa - w myśl socjalistycznej merytokracji, zakładającej, że z każdej klasy społecznej mniej więcej taka sama proporcja osób posiadała odpowiednie uzdolnienia, aby podjąć studia. Państwo miało zaś obowiązek zbudowania systemu, w którym każdy z tych uzdolnionych obywateli miał na to szanse. Jednocześnie zakładano, że „potrzebna jest praca ślusarza i profesora. Jedna i druga jednakowo powinna być szanowana i otoczona opieką. Ale aby być profesorem i badaczem, musi się mieć inne uzdolnienia aniżeli do wykonywania ślusarstwa" (Ci, którzy dzieło ojców swoich rozwiąża i udoskonala, KP 06/46). Demokratyzacja uniwersytetu nie miała i nie mogła mieć w nowej rzeczywistości charakteru przedwojennego „chodzenia z kagankiem oświaty” do mas, ale miała być wprowadzeniem prawa obrania wolnego zawodu dla każdego (Młodzież robotnicza i chtopska, GR 09/48).

Zasadniczym założeniem było to, że pochodzenie społeczne przekłada się na odpowiedni profil ideowy, a pochodzenie z klasy robotniczej lub chłopskiej gwarantuje posiadanie poglądów „demokratycznych”, a więc socjalistycznych i prorządowych. Już w 1946 r. „Kurier Popularny” zapowiadał:

${ }^{6}$ Typologii studentów powojennych na podstawie badań prowadzonych w Łodzi dokonał Jan Szczepański, wyróżniając studenta-uczonego, absolwenta-fachowca oraz działacza społeczno-politycznego, w dyskursie prasowym obecne były wszystkie te trzy typy, tworząc ogólny wzorzec studenta socjalistycznego (Szczepański 1963). 
Muszą to być ludzie [nowe kadry - A.Z.] nie tylko fachowo przygotowani do twórczego dzieła, ale także związani z nami duchowo, ideologicznie. Byłoby tak niewątpliwie, gdyby owi młodzi ludzie, którzy wychodzić będą z uniwersytetów i politechnik, byli pochodzenia chłopskiego i robotniczego. [...] Statystyka polska z roku 1935-36 wykazuje na 12.500 studentów zapisanych na pierwszy rok studiów w szkołach wyższych zaledwie $500 \mathrm{z}$ rodzin robotników fabrycznych $(4.190,100 \mathrm{z}$ rodzin robotników rolnych $(0,8 \%)$ i 600 studentów z rodzin chłopskich posiadających do 5 ha ziemi (5,1\%). Razem stanowi to $10 \%$ ogółu młodzieży. Ten stan rzeczy obecnie nieco tylko się poprawil, ciągle jeszcze z uczelni wyższych korzystają przede wszystkim dzieci warstw zamożnych, a więc zachowawczych, usiłujących zahamować rozwój dziejowy (Ci, którzy dzieło ojców..., KP 05/46).

Najważniejszą zmianą w imaginarium społecznym było wpisanie w horyzont możliwości klas niższych perspektywy podjęcia studiów. „Zaszczytny tytuł inżyniera, doktora czy magistra dzięki zmienionym po wojnie warunkom nosić więc po raz pierwszy będzie mógł syn małorolnego chłopa czy córka robotnika lub pracującego inteligenta" (Bramy wyższych uczelni szeroko otwarte, GR 08/48). Już same tytuły artykułów niosły wyraźne przesłanie podkreślające dostępność uczelni, używając metafor „otwartych drzwi”, „stania otworem”, „wypełniania się uczelni dziećmi robotników i chłopów". Proklamowana równość zawodów nie stała w sprzeczności z demokratyzacją szkolnictwa wyższego, ale miała jej sprzyjać.

Od 1948 r. system rekrutacyjny coraz częściej stawał się tematem artykułów prasowych. Jego działanie przedstawiane było jako „najbardziej paląca sprawa”, ze względu na zależność między składem społecznym kandydatów a składem przyszłej kadry. Jak starała się to zwięźle wytłumaczyć czytelnikom redakcja „Kuriera Popularnego", na kandydatów czekały trzy etapy rekrutacji:

Przede wszystkim kandydaci przejdą przez pierwsze sito już na komisjach terenowych Związków Zawodowych i Związków Samopomocy Chłopskiej oraz Rad Narodowych. Komisje te będą kierowały najzdolniejsze i najbardziej wartościowe jednostki spośród młodzieży robotniczej i chłopskiej nawet z najdalszych i najbardziej peryferyjnych ośrodków kraju. W ten sposób będzie można wyłowić talenty zagrzebane nawet na najbardziej głuchej prowincji [...] Drugim sitem, bezpośrednio już badającym osobiste kwalifikacje kandydata i dokonującym doboru studentów pod względem struktury społecznej i odpowiedniego zapotrzebowania na dane zawody, jest Komisja dla doboru kandydatów. Zadaniem jej będzie również podniesienie poziomu naukowego studentów, przez odpowiednią selekcję najlepszych i najzdolniejszych jednostek (Równy start dla mtodzieży, KP 06/48).

Nie były to komisje rekrutacyjne, o których zasługach dla błądzących studentów często można było przeczytać w prasie. Te miały na celu kompletowanie dokumentów i doradztwo w kwestii wyboru kierunku. Działały w dzielnicach i na terenie województwa, tworzone przez przedstawicieli lokalnych władz, Samopomocy Chłopskiej i ZMP. 
Trzecim sitem, kwalifikującym z czysto naukowego już punktu widzenia młodzież studiującą, będą siły profesorskie wyższych uczelni, odpowiedzialne za bezpośrednie wychowanie naukowców i specjalistów wszystkich gałęzi wiedzy (Równy start dla młodzieży, KP 06/48).

Prasa instruowała i wyjaśniała skomplikowane procedury. Aby wyrównać szanse już na poziomie rekrutacji, wprowadzono preferencyjne traktowanie niektórych kandydatów, co prasa przedstawiała jako konieczny krok dla wyrównania szans edukacyjnych. W taki sposób tłumaczono także istnienie roku wstępnego oraz kursów przygotowawczych:

Przy egzaminie uwzględnia się pochodzenie społeczne kandydata. Nie oznacza to jakiegoś faworyzowania, ale zrozumiałym jest, że dziecku chłopa czy robotnika, nie posiadającym odpowiednich warunków do nauki, pewne względy się należą. Jak widzimy więc dwie są linie wytyczne pracy komisji: 1) zlikwidowanie skutków wojny i 2) wyłowienie wartościowych jednostek ze sfer robotniczych i chłopskich, co sprowadza za sobą zmianę oblicza naszych szkół wyższych (Ponad 1000 osób zakwalifikowato się, DŁ 04/46).

Wiele miejsca poświęcono właśnie tym rozwiązaniom, co wiązało się nie tylko z podkreślaną wcześniej orientacją na przeszłość, związaną z narracją o wyrównywaniu krzywd i zadośćuczynieniu poprzednim niesprawiedliwościom, ale orientacją na przyszłość, a więc budową nowego porząadku, modernizacją, przebudową polskiej gospodarki, kultury, jak i całej struktury społecznej. Wprowadzenie kursów przygotowawczych było przedstawiane jako „wielki eksperyment”, który nigdy nie mógł się wydarzyć w przedwojniu, tylko odwaga i modernizacyjne cele powojnia stwarzały takie możliwości.

Niekiedy teksty prasowe przybierały formę reportażowych, chwytających za serce historii o poszczególnych osobach, z którymi czytelnik mógł się łatwo zidentyfikować. Poprzez ich sukces mógł zaś uwierzyć w osiągalność własnego. Niektóre historie przybierały niemal melodramatyczny ton, przedstawiając nie tyle celne przykłady, ile całe historie:

Pewnego dnia we wsi wywieszono afisze, głoszące, że można się zapisać na kursy przygotowawcze. Pokusa zgłosił się pierwszy. Po pomyślnym egzaminie został przyjęty. Teraz jest jednym z najlepszych uczniów.

- Trzeba tylko chcieć - wyjaśnia. Roboty jest dosyć, ale jak rozłożyć sobie dobrze pracę, to można ze wszystkim sobie poradzić. Sam zresztą jestem tego najlepszym dowodem, bo chociaż szkołę powszechną skończyłem 10 lat temu, to jednak nie pozostaję w tyle za innymi.

${ }^{7} \mathrm{Na}$ Uniwersytecie Łódzkim w pierwszej kolejności wprowadzano m.in. rok wstępny (Bińko 2001: 175). 
[...] Zdzisław Zwierz jest na historii. Jan Klatka na WSGW, Wincenty Dowgiełło studiuje na Politechnice - wszyscy oni byli kiedyśs słuchaczami kursu.

I tak, jak przodowali kiedyś w pracy zawodowej, tak i teraz dają przykład rzetelnego podejścia do nauki i na pewno za parę lat będą z nich wartościowi inżynierowie, lekarze i prawnicy (Dzielni w pracy i nauce, DŁ 02/51).

Z łatwością kolega Pokusa (jakże trafne nazwisko dla osoby decydującej się na nowe życie) dostał się na studia dzięki kursom przygotowawczym, ale także dobrej organizacji własnej pracy, która pozwoliła mu osiągać w nauce dobre wyniki. Sukces ten, jak sugeruje artykuł, to wynik nawyku ciężkiej i systematycznej pracy, który cechuje osoby pochodzące z klas pracujących. To oni bardziej się starają, doceniają możliwość nauki, posiadają etos pracy:

Należy przy tym zauważyć, że wbrew opiniom sceptyków poprawia się jakość nauczania i że młodzież robotniczo-chłopska pomimo początkowych trudności rzetelną pracą, wytrwałością i zdolnościami bije już studentów przedwojennych (Od przedwojennej pustyni kulturalnej..., GR 05/52).

Argumentowano, że młodzież ta podlegała nawet większej selekcji niż młodzież inteligencka. Tzw. „pływacy”, bazujący jedynie na swojej erudycji wyniesionej z domu, maskowali erudycją brak rzetelnej wiedzy. Ten argument był zresztą głównym orężem walki z przeciwnikami zbyt gwałtownych procesów demokratyzacji uczelni w obawie przed obniżaniem poziomu. Przedstawiciele klasy pracującej nie tylko mieli więc przyrodzony demokratyczny (socjalistyczny) światopogląd, ale także predyspozycje do ciężkiej pracy i jej dobrej organizacji. Takie cechy miały posiadać „nowe kadry”:

Ze szkół wyższych będą musieli wyjsść przyszli budowniczowie lepszego życia, ludzie, którzy nie tylko nie zniszczą dzieła ojców swoich, ale je rozwiną, udoskonalą. Muszą to być ludzie nie tylko fachowo przygotowani do twórczego dzieła, ale także związani z nami duchowo, ideologicznie [...]. Nie chcemy chować sobków, którzy swój interes osobisty wysuwać będą na czoło wszystkich poczynań. Tacy nie spełnią misji przypadającej inteligencji. Nie byłoby przecież różnicy między nimi a młodzieżą pochodzącą $\mathrm{z}$ warstw zamożnych. Tutaj nie chodzi tylko o zastąpienie młodzieży z jednego środowiska przez młodzież z drugiego środowiska. Chodzi o to, aby do szkół weszła młodzież o innej postawie życiowej, młodzież, której główną troskę nie stanowi urządzenie się w świecie jak najwygodniej, ale myśl o rozwiązaniu trudnych problemów życia politycznego, gospodarczego, społecznego, kulturalnego i naukowego. Rozwiązywaniu tych problemów zgodnie, w harmonii z najpiękniejszymi ideałami ludzkości, dźwiganymi przez masy chłopskie i robotnicze (Ci, którzy dzieło ojców swoich..., KP 06/46).

Podkreślano także konieczność zmiany podejścia samych rodziców-robotników i rodziców-chłopów, by nie kierowali się zapewnieniem osobistego dobrobytu dzieciom, „aby synowie byli »panami«”. Rodzice powinni zostać uświadomieni (sic!), 
że celem kształcenia ich dzieci jest „budowanie nowego świata i powszechnego dobrobytu a nie [...], aby jakiejś uprzywilejowanej grupie ludzkiej stworzyć lepsze warunki życia”.

Konstrukcja pojęcia „nowe kadry” wiązała się nie tylko ze zmianą ideologiczną niemal mechanicznie zależną od pochodzenia społecznego studentów, ale także z innym pojęciem - „nowe pokolenie”. Określenie to funkcjonowało poniekąd synonimicznie, jednak czynnik zmiany społecznej był zakorzeniony nie tyle w strukturze klasowej, ile demograficznej. Była to młodzież rozpoczynająca świadome życie w trakcie lub po wojnie, urodzona w latach 30. XX wieku, a więc niepamiętająca już zbyt dobrze czasów przedwojennych.

W rozwoju naszego uniwersytetu coraz większą rolę odgrywa to młode pokolenie łódzkich naukowców i kształtowanej przez nasz uniwersytet nowej inteligencji [...] nowe pokolenie to realna siła społeczna, która coraz wyraźniej zaznacza się w rozwoju naszego uniwersytetu i naszego miasta (UŁ po 5 latach, GR 01/50).

Sami studenci więc, nie jako ogól, ale jako przedstawiciele organizacji studenckich, pełniących w prasie rolę synekdochy, niejednokrotnie zabierali głos, definiując swoją rolę jako właśnie „nowych kadr” - „awangardy młodzieży postępowej”. W „Manifeście” z „Dziennika Akademickiego”, zarysowując ponownie podział na przedwojnie i powojnie, studenci definiowali swoją rolę i zadania następująco:

Chcieliśmy pokazać, że rozpoczynając nowe, powojenne życie jako studenci UŁ, nie tylko nie przyjęliśmy tradycji przedwrześniowych młodzieży akademickiej, lecz dążymy konsekwentnie do stworzenia nowych wartości i zapisania na naszym koncie przychodowym jak największej liczby pozycji - słowem do stworzenia nowego typu akademika. Pragniemy stać się elementem obywatelsko wyrobionym i twórczym. Poza nauką, która jest naszym zasadniczym celem, zajmujemy się również pracą kulturalną, społeczną i samokształceniową. [...] Jesteśmy częścią składową społeczeństwa i jeśli wyróżniamy się w tym społeczeństwie, to pragniemy, aby powodem wyróżnienia były nie białe czapki lub oznaki akademickie, jak niektórzy jeszcze sądzą, lecz dążymy do tego, aby na wyróżnienie zasłużyć nauką, pracą, postawą wobec życia i jego bieżących zagadnień. Chcemy, aby widziano w nas awangardę młodzieży postępowej, świadomie i konsekwentnie dążącej do realizacji ideałów demokratycznych (***, DA 10/46).

W podobnym tonie utrzymane były wypowiedzi studentów zrzeszonych w AZS „Życie”:

Żądamy nauki, żądamy wiedzy, która pozwoliłaby nam zbudować nowy świat, świat sprawiedliwości społecznej, w którym nigdy nie zaistniałaby możliwość wyzysku, w którym nie powtórzyłby się krwawy dramat ostatnich lat. Nie chcemy stuchać tylko martwych formułek, nie chcemy stać się rzemieślnikami, chcemy, by nasza mądrość była mądrością żywego człowieka, by wiedza, którą otrzymamy, była orężem postępu, byśmy się stali świadomymi bojownikami społeczeństwa, jego awangardą $\mathrm{w}$ wal- 
ce o prawa człowieka. Żądamy więc społecznego wychowania, żądamy uwidocznienia nierozerwalnej, z przyrodzonego prawa wywodzącej się spójni jednostki z ogółem. Żądamy podkreślenia tego prostego i zdawałoby się niewymagającego żadnego retuszu postulatu, demokracji, iż interes jednostki podporządkowany być musi potrzebie społeczeństwa. Żądamy po prostu demokratyzacji, demokratyzacji w pełnym tego słowa znaczeniu” (dwutygodnik AZS „Życie”, za: Nowe pismo akademickie, DA 10/46).

W ten sposób głos studentów w dyskursie był reprezentowany przez „bojowników społecznych”, którzy żądali nowego świata i demokracji. Głos całego środowiska prezentowany był jako spójny i zdecydowany. Nowe kadry miały stać ramię $\mathrm{w}$ ramię z robotnikami $\mathrm{w}$ procesie dziejowych zmian. Wkrótce reprezentację studentów, poza nielicznymi głosami korespondentów terenowych na uczelniach, w pełni przejęło ZMP oraz korespondenci terenowi, czyli wybrani studenci komentujący „od wewnątrz” uniwersyteckie sprawy. W ten sposób głosy pochodzące ze środowiska studenckiego przekonywały najlepiej zwykłego czytelnika o prawdziwej zmianie i zaangażowaniu studentów, którzy np. sami siebie zachęcali do wzmożenia dyscypliny pracy (Nauka w walce o wykonanie planu..., DŁ 10/50).

\section{Starzy i nowi profesorowie}

Nowe kadry miały dopiero nadejść. Rodziło się napięcie między nowym pokoleniem a przedwojennymi akademikami. „Stare kadry” powinny zasadniczo zostać zaklasyfikowane do powojnia, jednak było to niemożliwe. Podobnie jak studentów, podzielono więc inteligencję na tę „postępową”, przynależącą do powojnia, oraz „reakcyjną" resztę pozostającą w okowach przedwojnia. O tej pierwszej pisano także w nowy sposób; funkcjonowali oni jako „pracownicy nauki” czy „kadry akademickie", coraz rzadziej jako profesorowie czy akademicy, choć żadne z tych słów nie wyszło z użycia. Kadra profesorska miała więc przed sobą niezwykle ważną rolę do odegrania - miała wyszkolić nowe kadry, w tym nowe kadry akademickie na nowe czasy. Dydaktyka była najważniejszym obszarem działań naukowca, dodatkowo chodziło o dydaktykę postępową - kształcącą odpowiednią świadomość polityczną, a stawka była wysoka:

Wniosek generalny z dyskusji brzmi - o wynikach decyduje świadomość polityczna studiujących i personelu nauczającego. Decyduje, gdyż skłania do rzetelnego wypełniania obowiązków, pogłębiania wiedzy, kształtowania naukowego światopoglądu (Studenci UŁ podejmują ruch masowego przewodnictwa, DŁ 03/46).

Postępowych profesorów tworzących UŁ, a tak przedstawiała ich prasa, należało - tak jak studentów - otoczyć opieką społeczeństwa i państwa. W pierwszych latach powojennych brakowało mieszkań dla profesorów, apelowano więc o zadba- 
nie o ich warunki bytowe. Przykład stanowił choćby profesor $\mathrm{Sym}^{8}$, który musiał wykłady przygotowywać na łóżku, czy inni, niemający warunków do pracy ani na uczelni, ani w domu. Co interesujące, problem ten w żadnym artykule czy polemice nie był ukazywany jako roszczeniowy ani profesorskie oczekiwania nie były przedstawiane jako burżuazyjny sentyment - nawet gdy akademicy, podobnie jak literaci, otrzymywali stosunkowo atrakcyjne lokale (oczywiście nie wszyscy i nie od razu).

Próbowano obrazować zmianę zachodzącą w początkowo sceptycznej kadrze profesorskiej. Dawano też wyraz nieufności ze względu na jej pochodzenie klasowe i przedwojenne uwikłania. Pisano zatem o rosnącym zaangażowaniu, poczuciu misji, wreszcie coraz lepszym rozumieniu swojej roli w powojennym świecie:

Podstawowym osiągnięciem minionego roku jest poważne pogłębienie przeobrażeń zachodzących w świadomości większości pracowników naukowych, którzy coraz bardziej stają się nauczycielami-wychowawcami kadr specjalistów, przyszłych budowniczych socjalizmu ( $O$ wyższq uczelnię nowego typu, GR 10/51).

Akademicy mieli więc - w konfrontacji z samą rzeczywistością - uświadamiać sobie swoją nową rolę i w cudowny sposób z „zatwardziałych zwolenników starego systemu” zmienić się w apologetów nowego - „profesor musi zejść do roli pedagoga, nauczyciela, organizatora" (Przed Kongresem, GR 04/50). Pozbywając się starych nawyków, mieli nawiązać kontakt z masami i włączyć się do budowy nowego porządku. O ile grupę studentów można było kształtować niemal od nowa, profesorowie musieli „znaleźć wspólny język z masami”- dokonać przejścia z przedwojnia do powojnia. Prasa nawoływała i relacjonowała tę kluczową dla przyszłości kraju walkę o rząd dusz:

[...] by wszyscy ci, którzy tkwią jeszcze w kręgu starych nawyków i urazów dokonali wreszcie wyboru, by zrozumieli i wykorzystali dla dobra społecznego tę wielką szansę jaką dla postępu nauki stworzyły wielkie przemiany społeczne, podjęte i przeprowadzane przez obóz demokracji polskiej. Nie wszyscy bowiem, niestety, pracownicy nauki zdają sobie sprawę z dobrodziejstwa wyzwolenia się myśli ludzkiej z obcęgów, w jakich trzymała ją dyktatura kapitału i wstecznictwa. Im szybciej ogół pracowników nauki polskiej znajdzie wspólny język z polskimi masami pracującymi wykuwającymi w pocie i trudzie wśród olbrzymich trudności czasów dzisiejszych nowy lepszy ustrój społeczny, tym rychlej odbuduje się ze zniszczeń wojennych tak straszliwie okaleczona przez okupanta kultura polska. A sprawa odbudowy kulturalnej jest nie mniej ważna dla przyszłości naszego narodu jak dzieło odbudowy materialnej (Ludzie nauki muszq znaleźć..., KP 09/46).

${ }^{8}$ Zapewne chodzi o prof. Ernesta A. Syma (1893-1950) - biochemika i enzymologa, który tworzył na UŁ Zakład Chemii Lekarskiej (potem Katedra Chemii Ogólnej i Fizjologicznej na Wydziale Lekarskim UŁ), a w 1946 r. wyjechał do Gdańska. 
Profesor - czy od początku postępowy, czy neofita - miał więc być nauczycielem, ale nie scholastycznym belfrem niosącym z wyżyn nauki kaganek do mas, a zaangażowanym pracownikiem poświęcającym swemu zadaniu wiele troski i „ofiarnego wysiłku". Zadania, jakie stały przed środowiskiem naukowym, tak streszczał „Dziennik Łódzki” w 1949 r.:

Zadania jakie stoją przed nami w tej dziedzinie (przezwyciężenia zacofania nauki), dadzą się sprowadzić do następujących zasadniczych punktów:

1) Unowocześnienie zakresu i metod nauczania.

2) Roztoczenie należytej opieki nad młodymi naukowcami.

3) Zachęcenie zasłużonych profesorów i naukowców do rewizji ich przestarzałych poglądów na naukę (Wiedza to nie towar w kramiku, DŁ 11/49).

Tych spośród akademików, którzy nie zdołali się wyzbyć „przeżytków burżuazyjnego poglądu”, czekała marginalizacja. Czytelnik prasy śledził, jak na jej łamach dokonuje się zmiana, jak akademicy schodzą ze swych wież z kości słoniowej i stają się „robotnikami nauki”.

Poza głównym, dydaktycznym, celem prac akademików mieli oni także przyczynić się do uspołecznienia uniwersytetu - upowszechniać wiedzę i swoje działania. Mieli więc wygłaszać zewnętrzne wykłady o charakterze popularnonaukowym, odwiedzać świetlice fabryczne, pomagać studentom i angażować się w życie tak uczelni, jak i miasta, jego mieszkańców, a najlepiej całego kraju. W prasie regularnie donoszono, czym zajmują się łódzcy naukowcy, jakie prowadzą badania i jaki może to mieć pożytek dla społeczeństwa i rozwoju gospodarki. Pisano z dumą o zjazdach i konferencjach odbywających się w Łodzi, ale również o ogólnokrajowych i zagranicznych wydarzeniach, w których uczestniczyli tutejsi profesorowie reprezentujący robotnicze miasto (i socjalistyczną ojczyznę) na świecie. Pisano nawet o czasopismach naukowych publikowanych w Łodzi, większości uroczystości, a początkowo także o obronach doktorskich i mianowaniach profesorskich. Relacjonowanie spraw uczelni jako obszaru publicznego zainteresowania przybliżało świat akademii przeciętnemu czytelnikowi.

Uniwersytet, opisany jako uspołeczniony i bliski potrzebom społeczeństwa, musiał zejść z piedestału „czystej nauki”. Prasa przekonywała, że zmiana ta jest zupełnie naturalna i racjonalna:

Istnieje pewien dość utarty przesąd, że praktyczne wytyczenie działań społecznych stanowi wyłącznie domenę „polityków” i że tzw. „, czysta nauka” winna stać jak najbardziej z dala od polityki. Przesąd ten jest szkodliwy. W świetle tego przesądu pracowników nauki traktuje się jako swoistą kategorię ludzi, zamkniętych w ciszy swych gabinetów, pogrążonych całkowicie w kontemplacjach umysłowych. Aczkolwiek przesady tego rodzaju są śmieszne i może nawet paradoksalne, tym niemniej niebezpieczeństwo izolacji, biernej postawy, oderwania od życia społecznego jest zjawiskiem realnym i bynaj- 
mniej nie rzadkim wśród ludzi zajmujących się z zawodu pracą naukową (Rola nauki $w$ życiu odrodzonej Polski, DŁ 06/46).

Ważnym wydarzeniem intensyfikującym definiowanie roli nauki i naukowców był plan sześcioletni, ale także uchwalenie nowej Konstytucji w 1952 r., wzorowanej na radzieckiej. Przy okazji tego wydarzenia przypominano postępowe i demokratyczne tradycje „dawnej kadry naukowców”, nakładając nań raz jeszcze obowiązek przygotowania nowych kadr. Zaletą nowej Konstytucji i nowością miało być wyraźne określenie roli i obowiązków inteligencji, a więc i pracowników naukowych (rozdział 7 Konstytucji - Prawa i obowiązki obywateli9), jak tłumaczono w „Głosie Robotniczym":

W Konstytucji sprawa nauki zajmuje wiele miejsca, bo nauka ma wielkie znaczenie dla kraju demokracji ludowej, bo „nauka to badania prowadzone metodą marksistowsko-leninowską, to socjalistyczne przewidywanie, planowanie”. Konstytucja będzie służyła dalszemu rozwojowi nauki, kultury - narodowej w formie, socjalistycznej w treści, głęboko humanistycznej. Pracownicy naukowi w Polsce Ludowej mają poczucie użyteczności swej pracy [...]. Obowiązki inteligencji wiążą się w poważnym stopniu z gwarancją praw ogółu obywateli. Projekt Konstytucji nadaje obywatelom prawo do pracy, ale zapewnienie tego prawa należy w znacznym stopniu od pracowników umysłowych ekonomistów, nowatorów i racjonalizatorów, kadr inżyniersko-technicznych. Budownictwo socjalistyczne wymaga zatem specjalistów i pełnowartościowych kadr inteligencji (Prawa i obowiązki inteligencji, GR 04/52).

Wraz z ofensywą sześciolatki, od około 1950 r., naukowcy mieli podejmować coraz to nowe wyzwania w walce o jej realizację: „praca naukowa ma być powiązana ściśle z życiem, służąca socjalistycznej gospodarce, mająca na celu przyspieszenie budowy socjalizmu w kraju” (Rzadkie okazy roślin pomagają..., DŁ 01/53). Dzienniki z dumą donosiły o kolejnych przyjętych zobowiązaniach kadry akademickiej, takich jak: wyznaczenie dodatkowych godzin dyżurów, zużywanie mniejszej ilości odczynników w laboratoriach, wydanie dodatkowych publikacji czy poświęcenie pracy ważnym kwestiom społecznym, np. problematyce życia łódzkich robotników.

Innym mobilizującym akademików zabiegiem, nasilającym się w latach 50., była walka o pokój. W tym kontekście środowisko akademickie przedstawiane było jako mówiące jednym głosem, jednorodnie postępowe (Apel naukowców tódzkich, GR 03/55). Tak było w przypadku podpisywania apeli o pokój oraz pokojowe wykorzystywanie nauki czy w samym Plebiscycie Pokoju w maju 1951 r.:

Profesorowie i studenci młodego Uniwersytetu robotniczego miasta wyrazili swoją niezłomną wolę służenia sprawie pokoju i postępowej nauce. [...] Naukowcy i studenci

9 Art. 61 projektu nowej Konstytucji głosił: „Obywatele Polskiej Rzeczypospolitej Ludowej mają prawo do nauki”. Dz.U. 1952, nr 33, poz. 232, ISAP, http://isap.sejm.gov.pl [6.06.2014]. 
Uniwersytetu Łódzkiego potwierdzili, że są niezachwianymi bojownikami pokoju i postępu (Plebiscyt na uniwersytecie, DŁ 05/51).

W „Kronice Filmowej” relacjonującej to wydarzenie (PKF 22/51 „Narodowy Plebiscyt Pokoju, Repozytorium Cyfrowe Filmoteki Narodowej" 2014) profesorowie i młodzież uniwersytecka wymienieni są zaraz po „pierwszym wojowniku o pokój” Bolesławie Bierucie, górnikach ze Śląska i robotnikach. Zajmują w ten sposób miejsce przed chłopami i budowniczymi (oraz „postępowymi księżmi i zakonnicami”).

Oddzielnym tematem były już wspomniane nowe kadry, ale na polu akademickim - na poziomie lokalnej prasy miały to być przede wszystkim własne kadry naukowe Uniwersytetu Łódzkiego. Często poruszany problem studenckiej biedy i potrzeby stworzenia całościowego systemu świadczeń zapewniającego możliwość uczenia się miał dotykać w szczególności tych, którzy nie tyle uczyli się zawodu, ile mogliby się poświęcić nauce jako takiej i w przyszłości zasilić nowe kadry akademickie, kontynuujące tradycje postępowej grupy profesorów. Takie poświęcenie wymagać zaś miało znacznie lepszych warunków - stąd postulat ochrony i troski o studentów nabierał większej mocy w kontekście nowej kadry akademickiej:

Minimum. Powiedzmy od biedy wystarczy dla praktycznego wykonywania zawodu. Ale gdzie nowe zastępcy pracowników nauki, które przejmą po starszym pokoleniu trud dalszego przekazywania wiedzy? Gdzie uczeni, pracujący dla postępu?

Przykro to stwierdzić, ale nie wychowamy ich, dopóki nie poprawi się materialny byt rzesz studenckich. Dopóki nie zdejmie się z młodzieży balastu trosk i przyziemnych kłopotów. O tym trzeba poważnie pomyśleć (Jan drzemie na wykładzie, DŁ 09/48).

Nowe socjalistyczne kadry naukowców, czyli tysiące młodych lekarzy, inżynierów, ekonomistów, nauczycieli, musiały mieć zapewnione ścieżki rozwoju, a kariera akademicka musiała stać się równie atrakcyjnym wyborem dla młodych ludzi. Tymczasem wskazywano problemy, zapytując:

Kto ma być bowiem przyszłym wykładowcą na wyższych uczelniach: student pracujący i wystający przed dziekanatem w celu uzyskania odroczenia egzaminu? A może student - stypendysta, przedstawiciel owej przysłowiowej właśnie biedy studenckiej? Albo student - bywalec kawiarniany? Z pewnością żaden z nich ( $W$ trosce o ksztatcenie naukowców, DŁ 10/47).

Ważną grupą w tym procesie byli asystenci. Była to grupa nie tylko liczna, ale także kluczowa dla reprodukcji czy demokratyzacji kadry akademickiej. Podkreślano jej lepsze niż przed wojną położenie, stabilność i opiekę, „której nie zapewniał sanacyjny rząd” (Pod troskliwa opieka, DŁ 09/51). Kluczowa dla poprawy bytu tej grupy pracowników była reforma asystentury wzorowana na radzieckim kandydacie nauk - tak niszowy temat także poruszany był na łamach prasy codziennej, tłumaczono założenia reform i przedstawiano korzystne efekty. 
Więcej miejsca zajmowały apele o jasne kryteria awansu w naukowej karierze oraz ostrzeżenia przed rozpowszechnianiem się wśród asystentów reakcyjnych poglądów. Przestrzegano, iż „niejednokrotnie funkcje asystentów obejmują ludzie nastawieni wrogo do ustroju Polski Ludowej" (Robotnik - wzorem dla studiującej mtodzieży, DŁ 04/50). Poruszano także problem słabego przygotowania przyszłych naukowców, co miało wynikać:

[...] z przypadkowego doboru kandydatów. Absolwenci, którzy zamiast po ukończeniu studiów zgłosić się do pracy np. w przemyśle czy szkołach, w pierwszym porywie zapragnęli zostać naukowcami, nie zdając sobie sprawy ze swoich możliwości. Co gorsze, możliwości te nie były, jak dotychczas, przedmiotem wnikliwej analizy profesury, dziekanów, katedr... Nic więc dziwnego, że konsekwencje takiego „doboru” kadr są często opłakane, a poszkodowane są obie strony - młoda kadra i uczelnie (Naukowcy tódzcy dyskutuja, ŁEI 03/56).

Piętnowano brak przejrzystości procedur, nawołując po raz kolejny do socjalistycznej merytokracji - to zdolności, ale i umiłowanie zawodu miały decydować o awansie. Oczywiście pomiędzy tymi, którzy już zostali wybrani do kariery naukowej jako budowniczowie socjalizmu. Jak pisał „Głos Robotniczy” w 1952 r.:

Przekształcają się programy, treść i formy nauczania i nauki, zmienia się oblicze ideologiczne, nie tylko młodzieży ale i profesorów. Jesteśmy świadkami, jak stopniowo zanika dominujący dawniej typ uczonego, który zamykał się niby w wieży z kości słoniowej i kroczył na tak wysokich koturnach, że nie widać było już z nich życia i dokonujących się dokoła przemian (Od przedwojennej..., GR 05/52).

Zarówno role studentów, jak i profesorów uległy przedefiniowaniu, przypisano im nowe zestawy czynności, powinności, nowe określenia - tak dla stanu niechcianego, jak i proklamowanego czy docelowego. Następowała rekonstrukcja obiektów kształtujących imaginarium społeczne.

\section{Nauka i uniwersytet}

Głównym punktem odniesienia w konstruowaniu obiektu uniwersytetu pozostawał rekonstruowany wcześniej model liberalnej (przedwojnie) i socjalistycznej uczelni (powojnie). Forsowny przez Józefa Chałasińskiego uniwersytet uspołeczniony nie przebił się do prasowego dyskursu poza wypowiedziami samego autora (choć sam przymiotnik funkcjonował w prasie, służąc do opisu elementów uniwersytetu socjalistycznego) (Piskała i Zysiak 2013, Zysiak 2015). W mocy pozostawały więc zasadnicze podziały. Wzmacniane były poprzez rozpisanie również innych obiektów dyskursu na osi przedwojnie - powojnie, jak uczony intelektualny arystokrata vs. budowniczy socjalizmu, izolacja (czysta nauka) vs. zaangażowanie w sprawy 
społeczne (zaangażowana nauka), niekontrolowana swoboda vs. planowanie, elitaryzm vs. egalitaryzm. Wszystkie te elementy wiązały się z hasłem uspołecznienia nauki, które w zależności od kontekstu oznaczało zarówno użyteczność wiedzy, demokratyzację uniwersytetów, planowanie i dyscyplinę, a później także marksizm-leninizm, jako jedyną ramę działań naukowych. W 1948 r. w „Dzienniku Łódzkim” pisano:

Dotychczas zagadnienia nauki, uniwersytetów i w ogóle szkolnictwa wyższego stały raczej na uboczu zainteresowań polskiej opinii publicznej. A znowu profesorowie, badacze, cały aparat wyższego szkolnictwa, zamknięci za murami swych gabinetów i zakładów naukowych, na ogół stali z dala od spraw poruszających szerokie warstwy narodu. Nieliczne wyjątki potwierdzały tylko fakt nowego wyniosłego izolacjonizmu (Nauka bez izolacji, DŁ 01/48).

Niezwykle rzadko i tylko w początkowym okresie pojawiały się pozytywne elementy przedwojennej uczelni, jak poniższy fragment o relacjach na uczelni:

W przedwojennych warunkach studiów profesor był równocześnie wychowawcą i niejako duchowym ojcem studenta. Nie tylko bowiem wykładał dany przedmiot, ale wskazywał odpowiednią lekturę, rozjaśniał wątpliwości na seminariach, kształtując i urabiając typ umysłowy.

Dziś kontakt studenta z profesorem zaczyna się i kończy równocześnie na kilkugodzinnym wykładzie. Dlatego brak studentowi warunków, brak atmosfery, sprzyjającej wybitniejszemu rozwojowi intelektualnemu (Wokót naszych spraw, DA 05/46).

Jednak ani atmosfera, ani cenzura nie pozwalały na zbyt dużą dozę sentymentu wobec tradycyjnego/liberalnego uniwersytetu. Ważnym komponentem przedwojnia był przypisywany mu kapitalistyczny model gospodarki. Znalazło to wyraz $\mathrm{w}$ dwóch istotnych antykapitalistycznych postulatach wobec uniwersytetu:

- Wiedza to nie towar - mimo odejścia od idei „czystej nauki” podporządkowanie nauki potrzebom społeczeństwa miano zachować niezależność tworzenia wiedzy, bynajmniej nie od nacisków społecznych (czy politycznych), ale rynkowych. Pisano więc, że „WIEDZA TO NIE TOWAR W KRAMIKU” (DŁ 11/49) jak w kapitalizmie - w Polsce Ludowej służy budowie społeczeństwa, nie prywatnym majątkom i wyzyskowi.

- Uniwersytet to nie przedsiębiorstwo - owszem, uczelnia ma działać sprawnie niczym fabryka, współdziałać z całym systemem produkcji, zarządzać i planować, ale nie w logice zysku, ale efektywności i postępu ${ }^{10}$. Konsekwencją tego założenia było zagwarantowanie finansowania nauki, co miało uniezależnić ją od kapitału i zapewnić prawdziwą wolność i autonomię: „Nauka i naukowcy sami siebie finansować nie mogą" (Ludzie nauki muszq̨ znaleźć..., KP 09/46).

\footnotetext{
10 Także „zakład pracy” nie był już przedsiębiorstwem nastawionym na zysk, ale na produkcję.
} 
Proces dziejowy, prowadzący od uniwersytetu liberalnego do socjalistycznego miał być nieunikniony, a jak przedstawiano to w prasie, zwłaszcza po 1948 r., prawda i postęp nie stały po stronie uniwersytetu przedwojennego: „Stary, liberalny uniwersytet z roku na rok obumiera. Wypiera go nowa, socjalistyczna uczelnia. [...] Uniwersytet objęła w posiadanie młodzież Polski Ludowej” (Dyscyplina studiów i zespołowa praca..., GR 09/51). Jak pisał w 1953 r. „Dziennik Łódzki”, uczelnie „służą jednemu celowi: kształtowaniu nowego oblicza nauki w służbie mas pracujących dla pokojowego budownictwa socjalistycznego" (Wspótpraca wydawnicza, DŁ 01/53) - oblicze to było dopiero kształtowane, trwała walka i wiele pozostawało do zrobienia. Był to standardowy zabieg, służący zarówno mobilizacji, jak i zneutralizowaniu wszelkich niedociągnięć i problemów, które w trwającym procesie są przecież sprawą naturalną: „Choć nowa świadomość w zasadzie zwyciężyła, to przecież tu i ówdzie natrafia się na resztki idealistycznych poglądów. [...] W walce z tymi odchyleniami Uniwersytet Łódzki wzmacnia się i prostuje, dążąc do tego, by najskuteczniej służyć ludowi pracującemu" (To już prawie dziesięć lat, ŁEI 07/54).

\section{Funkcje uczelni $\quad$ UNIWERSYTET}

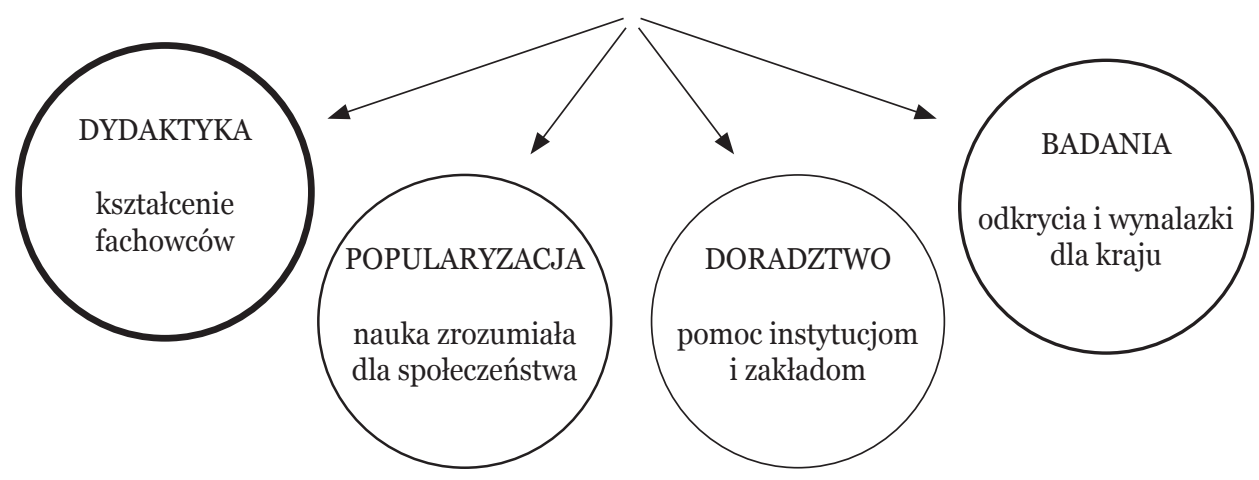

Rysunek 2. Zestawienie zadań uniwersytetu socjalistycznego w okresie powojnia Źródło: opracowanie własne.

W powojennej optyce pojawiały się zasadniczo cztery grupy funkcji, jakie miał pełnić nowy socjalistyczny uniwersytet (rys. 2)7:

- Dydaktyka - uniwersytet miał przede wszystkim pełnić funkcje dydaktyczne, stać się miejscem kształtowania kadr i umożliwiać rozwój kraju. W przypadku UŁ po 1948 r. z postępowego ośrodka badawczego, kuźni socjalistycznej myśli, miał stać się on przede wszystkim centrum dydaktycznym, dostarczającym fachowców rozwijającej się gospodarce: 
Uniwersytet powstały z woli władzy ludowej powinien całe swe wysilki skoncentrować w tym kierunku, by jak najlepiej służyć ludowemu państwu, dając społeczeństwu nowe kadry inteligencji, uzbrojonej w oręż prawdziwej, głębokiej wiedzy. [...] Chodzi bowiem o to, by młodzież kończąca studia była jak najlepiej przygotowana do czekającej ją pracy zawodowej (Witamy krajowy zjazd rektorów i dziekanów uniwersytetów, GR 01/54).

Pełniąc funkcje dydaktyczne, uczelnie miały za zadanie wspierać proces demokratyzacji, w tym sprawiać, by młodzież robotniczo-chłopska czuła się w tej obcej dla niej instytucji jak u siebie. Cele dydaktyczne miały zostać oparte na kilku istotnych komponentach, takich jak: walka o jak najwyższy poziom studiów, odpowiedni ideologiczny profil edukacji, dopasowanie działań do potrzeb kraju.

- B a d a ni a - drugą najważniejszą funkcją, jaką prasa przypisywała uniwersytetowi, była funkcja produkcji nowej wiedzy. Kraj dokonywał niełatwego skoku modernizacyjnego, oprócz kadr potrzebował technologii, nowoczesnych technik pracy, wiedzy o organizacji pracy etc. Nie zapominajmy, że trwała zimna wojna, odrzucono plan Marshalla, więc na państwach socjalistycznych spoczywał cały ciężar udowodnienia światu przewagi socjalizmu nad kapitalizmem. Jednocześnie kult wiedzy i niemal religijne - i oświeceniowe - jej zawierzenie zwiekszały nacisk na prowadzenie badań i rozwój wszystkich dziedzin wiedzy. Słabsza obecność tego wątku związana jest z wydzieleniem funkcji badawczych do specjalistycznych instytutów poza uczelniami oraz Polskiej Akademii Nauk, a pozostawienie uniwersytetom przede wszystkim funkcji dydaktycznych. Badania i rola Uniwersytetu Łódzkiego właśnie jako centrum badawczego pojawia się jednak w prasie wielokrotnie, czy to we wspominanych sprawozdaniach z działalności katedr, konferencji, czy w artykułach popularnonaukowych.

- Popularyzacja - uspołeczniony uniwersytet był zobowiązany do upowszechniania wyników i samej tematyki swoich badań oraz przedstawiania w przystępny sposób reszcie społeczeństwa, czym się zajmuje, jakby referując własne działania tym, którzy umożliwiają mu istnienie. Był to świadomy zabieg oswajania uniwersytetu i przybliżania jego działalności reszcie społeczeństwa, ale i ksztaltowania jego misji upowszechniania nauki. Nie brakowało więc notek o otwartych wykładach czy większych artykułów o znaczących uroczystościach na uczelni: od przyznawania stopni doktorskich po późniejsze narady produkcyjne. W „Łódzkim Ekspresie Ilustrowanym” w latach 50. publikowano cykl artykułów pt. „Z łódzkich ośrodków badawczych”, omawiajacych działania łódzkich naukowców - nawet jeśli nie wszystkie słowa użyte w opisie naukowych przedsięwzięć mogły być znane szerszej publiczności, to w artykułach starano się wytłumaczyć, czym i po co dana katedra się zajmu- 
je, ze szczególnym uwzględnieniem praktycznego wymiaru tych badań i ich przekładalności na życie zwykłego człowieka.

- D o r a d z two - najrzadziej przypisywaną w prasie funkcją uniwersytetu było doradztwo. Funkcje te przynależały raczej do uczelni technicznych, nie była to tradycyjna gałąź aktywności uczelni. Uczelnie, a także uniwersytety były jednak miejscami produkcji wiedzy, pełniąc funkcje badawcze, i tylko dodatkowym krokiem miało być przełożenie tej praktycznej wiedzy na konkretne działania, mające pomóc w funkcjonowaniu zakładów pracy czy instytucji. W 1955 r. „Głos” zaproponował krótką definicję wszystkich zadań uniwersytetu:

Spełnia więc Uniwersytet wieloraką rolę. Kształci kadry nauczycieli, prawników, pracowników przemysłu [...]. W ramach prac badawczych opracowuje problemy i zagadnienia regionu. Popularyzuje naukę wśród mieszkańców Łodzi i województwa. Niesie fachową pomoc instytucjom i zakładom przemysłowym (Rola uniwersytetu $w$ robotniczej Łodzi, GR 04/55).

Dodatkowym komponentem, agresywnie forsowanym po reformie, wraz z nasilającą się stalinizacją, był ideologiczny profil uczelni. Wcześniej pisano raczej o postępowym, demokratycznym czy otwartym charakterze uczelni, maskując jawne odniesienia do socjalizmu, nie mówiąc już o marksizmie-leninizmie. Tak jak na poziomie politycznych przemówien, było to związane przede wszystkim z próbą włączenia w projekt modernizacyjny jak najszerszych grup społecznych. W późniejszym okresie jednak jawnie i dość agresywnie, zwłaszcza w „Głosie Robotniczym”, zaczęto forsować jedyne słuszne podejście do nauki, przykładowo:

Zadaniem organizacji partyjnej będzie walka o powszechne uznanie przodownictwa marksizmu i leninizmu w nauce. Musimy ułatwić przechodzenie dotychczasowych materialistów - formalistów na pozycje ideologiczne marksizmu, będziemy to czynić nie drogą zaciemniania przeciwieństw ideologicznych, czy ich klajstrowania, ale drogą okazywania ich w pełnym świetle, odsłaniania ich korzeni klasowych, a w konsekwencji drogą nieuniknionego wyboru między pozycjami postępu i wstecznictwa (Kadry decydują o wszystkim, GR 10/49).

Postępowa droga oznaczała także finalne osiągniecie pełni i złączenie się nauki z pracą, uczelni z zakładami pracy, akademików z robotnikami i chłopami poprzez wspólny horyzont ideologiczny.

\section{Demokratyzacja i socjalistyczna merytokracja}

Dyskusje wokół normatywnych modeli uniwersytetu, wieloetapowa reforma mająca na celu stworzenie uniwersytetu socjalistycznego oraz przebudowa imaginarium 
społecznego wyznaczały początek zmiany. Jednocześnie rok 1956 stanowił załamanie całego projektu przebudowy imaginarium społecznego. Nastąpiło przełamanie wcześniejszego języka, doboru tematów, nawet jeśli ogólna idea systemu nie została zanegowana, to wiele kwestii bardziej szczegółowych stało się przedmiotem polemiki, śmielej pisano o biedzie, granicach demokratyzacji, przywilejach dostępnych partyjnym czy antysemityzmie. Jednak początkowe rozluźnienie, a potem wzmożona reakcja po wydarzeniach w Poznaniu (ale także w Łodzi, kiedy siłą stłumiono strajk tramwajarzy w 1957 r.) stanowią końcową cezurę okresu powojennej przebudowy imaginarium społecznego

W niniejszym artykule starłam się zrekonstruować nie tyle zmiany w przedstawianiu uczelni w prasie, ile szerszą zmianę społeczną, warunkującą funkcjonowanie społeczeństwa. W każdym historycznym momencie możemy mówić o pewnym repertuarze praktyk, dostępnym danej grupie społecznej - są to działania, które uznawane są za naturalne, dopuszczalne, a nawet pożądane, wiadomo, jak je podejmować. W powojennym okresie zaszła ważna zmiana w tym obszarze, polegająca na modyfikacji całościowej ramy pojęciowej i przebudowie repertuaru praktyk - była to także część procesu konstruowania socjalistycznego imaginarium społecznego. Jak pisał „Dziennik Łódzki”: „wśród wielu zdobyczy Polski Ludowej jedno z pierwszych miejsc zajmuje udostępnienie nauki najszerszym rzeszom naszego społeczeństwa” (Otwarta droga, D€ 50/o1), a wtórował mu „Kurier Popularny”, donosząc, iż „z pośród wszystkich ruchów społecznych socjalizm ożywiony był zawsze największą troską i dbałością o rozwój oświaty, nauki i sztuki” (Ludzie nauki muszą znaleźć..., KP 09/46). Najważniejszą konsekwencją tej zmiany miała być demokratyzacja i uspołecznianie uczelni - próba budowy uniwersytetu socjalistycznego.

Doszło zatem do ustanowienia nowej konstelacji obiektów, przyznania sprawczości i rozbudzenia pragnień edukacyjnych wśród wielu grup społecznych, przede wszystkim klas pracujących. Dla większości Polaków perspektywa podjęcia studiów wyższych, jeszcze na uniwersytecie, znajdowała się poza wyobrażoną ścieżką życia. Dla niektórych nagle, dla innych z roku na rok perspektywa podjęcia studiów stawała się realna, okazała się wyborem wartym rozważenia, tak w perspektywie własnego życia, jak i życia swoich dzieci, a nawet współpracowników i sąsiadów. Studia wyższe miały być dostępne dla każdego, co więcej - miały być one niemal zaprojektowane specjalnie dla klasy pracującej. Dodatkowo studiowanie i praca uniwersytetu stały się sprawami publicznymi. Indywidualne decyzje przez kolektywny socjalistyczny zryw stały się także publiczne, już nieprzezroczyste, nie zamknięte w prywatnym życiu, ale godne sproblematyzowania. Zdanie sobie sprawy z tej próby przebudowy imaginarium społecznego jest kluczowe dla pełniejszego zrozumienia powojennego życia polskich uczelni, także Uniwersytetu Łódzkiego. 


\section{Literatura}

Anderson, B., O’Gorman R. (1997). Wspólnoty wyobrażone: rozważania o źródtach i rozprzestrzenianiu się nacjonalizmu. Kraków: Znak.

Bell, A. (1991). The Language of News Media. Oxford: Blackwell.

Bińko, B. (2001). Skąd przychodzili, dokąd zmierzali... aspiranci pierwszego rocznika Instytutu Kształcenia Kadr Naukowych przy KC PZPR. W: T. Szarot (red.). Komunizm: ideologia, system, ludzie. Warszawa: Neriton.

Curry, J.L. (1990). Poland's Journalists: Professionalism and Politics. Soviet and East European Studies 66. Cambridge - New York: Cambridge University Press.

Garbowski, Ch. (2012). Imaginarium w kulturze popularnej. W: J.P. Hudzik, J. Kłos, Ch. Garbowski (red.). Charlesa Taylora wizja nowoczesności: rekonstrukcje i interpretacje. Warszawa: Oficyna Wydawnicza Łośgraf.

Grabham, E., Cooper, D., Krishnadas, J., Herman, D. (2008). Intersectionality and Beyond: Law, Power and the Politics of Location. London - New York: Routledge.

Howarth, D.R., Norval, A.J., Stavrakakis Y. (2000). Discourse Theory and Political Analysis: Identities, Hegemonies, and Social Change. Manchester - New York: Manchester University Press.

Kochanowicz, J. (2000). ZMP w terenie: stalinowska próba modernizacji opornej rzeczywistości. Warszawa: Trio.

Leder, A. (2014). Prześniona rewolucja. Ćwiczenie z logiki historycznej. Warszawa: Wyd. Krytyki Politycznej.

Mautner, G. (2010). Language and the Market Society: Critical Reflections on Discourse and Dominance. London: Routledge.

Narodowy Plebiscyt Pokoju PKF 22/51. b.d. Repozytorium Cyfrowe Filmoteki Narodowej. http://www.repozytorium.fn.org.pl/?q=pl/node/7846 [11.09.2016].

Nowak, W.M. (2008). Spór o nowoczesność $w$ poglądach Charlesa Taylora i Alasdaira MacIntyre'a: analiza krytyczna. Rzeszów: Wyd. Uniwersytetu Rzeszowskiego.

Piskała, K., Zysiak, A. (2013). Świątynia nauki, fundament demokracji czy fabryka specjalistów? Praktyka Teoretyczna, 3(9), http://www.praktykateoretyczna.pl/PT_nr9_2013_ Po_kapitalizmie/11.Piskala,Zysiak.pdf [11.09.2016].

Spodenkiewicz, P. (2008). Sprawa Marii Tyrankiewiczówny. W: J. Żelazko (red.). Rok 1945 $w$ Łodzi: studia i szkice. Łódź: IPN.

Szczepański, J. (1963). Socjologiczne zagadnienia wyższego wykształcenia. Warszawa: PWN.

Taylor, Ch. (2004). Modern Social Imaginaries. Durham: Duke University Press.

Taylor, Ch. (2007). A Secular Age. Cambridge, Mass: Belknap Press of Harvard University Press.

Taylor, Ch. (2010). Nowoczesne imaginaria społeczne. Kraków: Znak.

Taylor, Ch. (2012). Źródła podmiotowości: narodziny tożsamości nowoczesnej. Tłum. M. Gruszczyński. Warszawa: Wyd. Naukowe PWN.

Zysiak, A. (2015). Science for Modernization: Between a Captive and Egalitarian University - The University of Lodz, 1945-1952. Science in Context. 28 (2): 215-236. 


\title{
"The gates of the universities wide-open for the working classes!" Post-war reconstruction of the social imaginary and the project of socialist university
}

\begin{abstract}
Mobilization is a key for any modernization attempt. It was true also for rebuilding of Poland after 1945 and designing a new socialist university. Taking as a starting point the social revolution argument, interpreting the WWII and postwar time as a period of profound change of Polish society, I assume that this change brought a deep reconstruction of social imaginary and creation of educational desires among working classes. A conceptual horizon undergone irreversible shift. A common understating, personal expectations, ideal types as well as knowledge about our relation towards the world and other social groups went trough a profound revisions in a result of both the war and the postwar reconstruction. What was a role of universities in this new constellation of meanings? What duties and privileges were assigned to professors, students, working classes in daily press? The article offers an analysis of postwar media not as a propaganda tool, but a medium which reconstructed meanings. Educational desires evoked, horizons of expectations widened for those who never before could imagine enrolling to university.
\end{abstract}

KEYWORDS: socialist university, press, new professionals, social imaginary, postwar

CYTOWANIE: Zysiak, A. (2016). „Bramy uniwersytetu otwarte dla klas pracujących!” Powojenna przebudowa imaginarium społecznego i projekt uniwersytetu socjalistycznego. Nauka i Szkolnictwo Wyższe. 1(47): 53-86. DOI: 10.14746/nisw.2016.1.2. 